Enhancing comprehensive measurement of social impacts in S-LCA by including environmental and economic aspects

\author{
Journal Article \\ Author(s): \\ Zimdars, Christopher; Haas, Adrian; Pfister, Stephan (iD \\ Publication date: \\ 2018-01 \\ Permanent link: \\ https://doi.org/10.3929/ethz-b-000129780
}

Rights / license:

In Copyright - Non-Commercial Use Permitted

Originally published in:

The International Journal of Life Cycle Assessment 23, https://doi.org/10.1007/s11367-017-1305-z 
This is a post-peer-review, pre-copyedit version of an article published in The International Journal of Life Cycle Assessment. The final authenticated version is available online at: https://doi.org/10.1007/s11367-017-1305-z

\title{
ENHANCING COMPREHENSIVE MEASUREMENT OF SOCIAL IMPACTS IN S-LCA BY INCLUDING ENVIRONMENTAL AND ECONOMIC ASPECTS
}

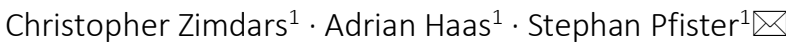 \\ ${ }^{1}$ Institute of Environmental Engineering, Chair of Ecological System Design, ETH Zurich, 8039 Zurich, \\ Switzerland \\ $\triangle$ Stephan Pfister, Email: pfister@ifu.baug.ethz.ch
}

\section{Keywords}

Activity variables · Added value $\cdot$ LCA · Social impacts · Social Life Cycle Assessment (S-LCA) · Sustainability

\begin{abstract}
Purpose. Measurability becomes a key question in the assessment of the sustainability of products and services. As the LCA has proven its capability of measuring environmental sustainability over the last decades, the S-LCA (Social Life Cycle Assessment) seems promising as a way to cover the social dimension of sustainability within a similar framework. For operability reasons, working hours are commonly used as a single metric in product orientated S-LCA studies, even though major stakeholder groups are excluded by doing so. This paper shows how this shortcoming can be overcome through the introduction of the measurement of additional activity variables and explores different ways of implementing these variables.

Methods. This work suggests introducing the activity variables Biophysical Pressure and Added Value in addition to the commonly used working hours of involved labour forces. Biophysical Pressure reflects both the negative influence of the degraded natural environment on the affected humans in addition to the direct health effect covered by standard LCA. Added Value represents the potential benefits for stakeholders due to financial investments in production. The new activity variables are derived from the MRIO database "Exiobase", and coupled with social risk indicators from the "Social Hotspot Database". Finally, the qualitative risk classes are transformed to quantitative units and normalized to allow for a better interpretation and an optional aggregation of the three variables into a final social impact score.
\end{abstract}

Results and discussion. In order to test the method's applicability, the social impacts of products and services from two different product systems were calculated and compared. Three t-shirts and four residential housing heating systems were assessed by the developed method and compared on the basis of their respective functional units. Major differences between the social impact measured only by working hours and social impact measured by the aggregation of the three quantitative units were observed, especially since the Added Value (social benefits) dimension and working hours contrasted regionally. While the concept is functional, there are limitations related to the MRIO inventory data and to the interpretation of results, therefore sensitivity analyses were applied.

Conclusion. The developed S-LCA method shows a promising way to extend the range of stakeholders affected by the life cycle of a distinct product by adding new variables. While constraints of MRIO data concerning detailed product system representation currently limit the approach, it allows one to identify potential social hotspots in complex product systems. 


\section{Introduction}

Today's society places enormous stress on the earth, its natural resources and living spaces (Valdivia et al. 2013). Since the United Nations Conference on Environment and Development (UNCED) in Rio de Janeiro in 1992, the terms of sustainability, sustainable development and its measurement have become increasingly important (United Nations 1993). According to the most common definition, sustainability and sustainable development contain three pillars of relevance: the environment, the economy and civil society (Brundtland 1987). However, a comprehensive assessment of sustainability has so far been limited, with most quantitative studies focusing on the economic dimension (Ness et al. 2006). Additionally, the social dimension is more difficult to assess quantitatively than the environmental impacts are (Benoît et al. 2010).

Life Cycle Assessment (LCA) has the potential of being an adequate method for the measurement of these pillars because of its holistic approach and capability to provide a quantitative value. The environmental LCA (E-LCA) shows, due to its long historical background, a high degree of standardisation and is therefore currently already widely used. Social Life Cycle Assessments (S-LCA) focus on the social dimension of sustainability and on the measurement of human well-being (Klöpffer and Grahl 2014). One major aim of an S-LCA is to provide support for decisions regarding social impacts related to the life cycle of a functional unit (e.g. a product), either for product comparison or for improving supply chains. By including the entire product life cycle in the assessment, the S-LCA offers a more holisticperspective on the impacts of products than is provided by comparable criteria based decision tools (e.g. fair trade labels) (Jørgensen 2013), and is therefore suitable for hotspot analysis.

While the research on S-LCA is in rapid development, earlier research is still the most cited and thus relevant in S-LCA (Mattioda et al. 2015). Norris (2006) questions if the structure of LCA is adequate for the controversial S-LCA and suggests an additional attribute related instrument (Life Cycle Attribute Assessment, LCAA). Dreyer et al. (2006) place the involved companies and their social responsibility into the center of their research, even though the products remain the point of reference. Weidema (2006) emphasises the construction of a complete measurement framework for social impacts based on the concept of Quality Adjusted Life Years (QALYs). In 2009, the Guidelines for Social Life Cycle Assessment of Products (UNEP/SETAC 2009, GSLCA) tried to unite the existing research streams by providing a general procedure. Since the GSLCA do not recommend specific impact assessment methods, researchers have recently developed various social life cycle impact assessment (S-LCIA) methods, as reviewed for instance by Chhipi-Shrestha et al. (2015). The methodology of S-LCA in general finds itself in a continuum of approaches using, on one hand, generic databases and on the other, product and site specific assessments (Martinez-Blanco et al. 2015). The former brings the advantage of reproducibility, but clearly lacks on case specificity. The latter approach is time and resource intensive and is usually accompanied by restrictions regarding the stakeholder representation or included life cycle phases. Chhipi-Shrestha et al. (2015) even argues that a field-based S-LCA of the entire life cycle of a product is impractical.

A promising dataset for carrying out a generic S-LCA was recently introduced by Benoit-Norris et al. (2012) as the Social Hotspot Database (SHDB). It primarily supports the associated impact assessment approach: The social scoping model that should identify "hotspots" of social impacts (Benoit-Norris 2012). Due to the impracticability of assessing impact pathways throughout complete supply chains in detail, activity variables can be used to measure the social impacts of a product indirectly. The most common activity variable (also used in the SHDB approach) is "working hours of involved labour forces" (Benoît Norris 2014). Activity variables have a similar function as inventory flows in LCA.

Another pioneer approach of an impact assessment method that includes social well-being was developed in 2013 in the EU project PROSUITE (Prospective Sustainability Assessment of Technologies, Blok et al. 2013) using the THEMIS database (Gaasbeek and Meijer 2013). It relies methodologically on the work of Bo Weidema (Weidema 2006) and uses six quantitative indicators for the measurement of social impacts: knowledge-intensive jobs, total employment, global income inequalities, regional income inequalities, child labour, and forced labour. Moreover, the focus of the method lays rather on the introduction of technologies, not on products or product baskets. 
As social impacts are strongly related to receptors (affected stakeholders), the GSLCA suggested five major stakeholder groups to be considered in an S-LCA: Workers, Local Community, Society (national and global), Consumers and Value Chain Actors. In their S-LCA review, Wu et al. (2014) stated that most of the methods emphasize the stakeholder group of workers and thus neglect social impacts on other stakeholder groups. Another issue is the interaction of economic, environmental and social aspects: while each sustainability pillar is to be addressed individually, they are also interconnected, since environmental impacts adversely affect society, while economic benefits can improve social conditions. These aspects have not been integrated so far in S-LCA methods based on the SHDB.

The goal of this work is to provide an operational method for S-LCA that (a) considers social impacts in relation to a more comprehensive selection of stakeholders by introducing two additional activity variables besides Working Hours to enhance the coverage of stakeholder groups, (b) account for positive social effects of a product within the S-LCA method and (c) to provide a flexible tool to calculate S-LCA results based on the developed methods.

\section{Methods and Data}

Our method is built within the frame of the LCA-related ISO norms 14040 and 14044 (ISO 2006). With this, we follow the general suggestion of the GSLCA (UNEP/SETAC 2009). Phases 1 and 4 of an LCA (i.e. Goal and Scope Definition and Interpretation, respectively) are case specific and not the focus of the methodological contribution of this work. The focus lies on the Life Cycle Inventory Analysis (LCl) and Life Cycle Impact Assessment (LCIA) as outlined in Figure 1. The method is based on a combination of different approaches and required a multitude of normative choices. Therefore we provide a default version of the method, and test the most relevant aspects in the sensitivity analysis, as described below. In order to increase the applicability and reproducibility of our method, we developed a software tool (Haas et al. 2017). For the full version, the appropriate database licences are needed, however for scientific purposes the tool is freely available online without SHDB data: https://tinyurl.com/SLCA-Haas.

\section{Triangulation Approach:}

In S-LCA, the activity variable Working Hours is commonly used to connect supply chain activities to various potential social impacts. However, this approach mainly represents the stakeholder group Workers. To include Local Community, Society and Value Chain Actors as well, the Triangulation Approach, often used in empirical social science (Flick 2008), is applied. This approach offers the prospect of enhanced confidence in an insecure methodological environment by assessing possible results from more than one angle (Bryman 2012). On this account, the following two additional activity variables are introduced:

1) Biophysical Pressure (BP) is understood here as the embedding circumstances related to the natural environment of an affected social community (Local Community and Society). The basic rationale is that human beings are living in natural environments and are therefore dependent on it and influenced by it beyond the pure health damage or ecosystem quality loss that are quantified in standard LCA (e.g. smog or destruction of ecosystems is affecting quality of life generally). This connection is also highlighted in literature (WRI 2005, Hicks 2016).

2) Added Value (AV) is differentiated into increased tax and different levels of salaries to account for how the investment of money into a specific sector or product results in economic benefits for the society. In addition to purely economic assessments, we address how Value Chain Actors or Societies in different regions of the world are influenced in their well-being. Depending on the social and political conditions of the affected locations, this can increase welfare of the involved stakeholders to different extents. 
It has to be noted that these indirect social effects measured through the activity variables BP and AV might be considered double counting in a full sustainability assessment (Life Cycle Sustainability Assessment, LCSA). Double counting could occur since social effects measured by one part of an LCSA (e.g. Health impacts measured by an E-LCA) are counted again by another part of the full sustainability assessment (e.g. also measured by the S-LCA). However, we only aim to account for the indirect effects of economic and environmental consequences on social aspects, which are correlated with the economic and environmental impacts quantified in specific assessments on those dimensions, even if they share part of the cause-effect model (cf. Figure S1 in Supplementary Material). An example is smog in cities, which causes health impacts but also heavily impacts quality of life since outdoor activities are restricted.

Since regional details are crucial to determine the inventory and impacts of product systems in S-LCIA, regionalized assessments are necessary to account for social impacts. However, to date no databases exist that allow for quantifying social impacts on a similar level of detail as process-based inventories in E-LCA, and therefore Input-Output based LCA approaches (IO-LCA) based on multi-regional input-output tables (MRIO) are applied. The introduction of the two additional activity variables required the use of the two MRIO-based databases SHDB (Benoit-Norris et al. 2012) and EXIOBASE (Wood et al. 2015), as described below.

FIGURE 1

\subsection{Life Cycle Inventory (LCI)}

In the first step of determining the inventory, technosphere data are assembled and related to the functional unit (ISO 2006). As is common for an Economic IO-LCA, this connection happens to be the monetary equivalent value invested in the Country Specific Sectors (CSS) related to the foreground processes of the analysed product system. In the following, the two MRIO-based databases and their merging, used for the $\mathrm{LCl}$, are described:

\section{EXIOBASE}

The EXIOBASE v2.2.2 database is based on the System of Environmental Economic Accounts (SEEA) and enables one to assess production-related impacts of consumption (Wood et al. 2015). The database includes economic data of 43 individual countries that account for more than $90 \%$ of the global GDP. The remaining countries are assigned to five Rest of World (RoW) groups. Each country's economy is split into 163 sectors. Additionally, the database includes a selection of environmental exchanges and detailed information on added value for each CSS. Further data characteristics are provided in the Supplementary Material (section S2).

\section{Social Hotspot Database (SHDB)}

The SHDB consists of three essential parts covering the MRIO results, the activity variable (working hours) and the social risks (Benoit-Norris et al. 2012). The trade between the CSS (sector inputs and outputs) was derived from the Global Trade Analysis Project database, version 7 (GTAP7), and includes 113 countries split into 57 CSS. Aside from the different country and sector resolutions (comparison in the Supplementary Material section S2), this part of the SHDB is similar to the economic data from EXIOBASE.

The labour intensities of the respective sectors (amount of hours worked per monetary output) is the core activity variable used in SHDB.

Database Merging 
From a data quality point of view, the two databases have complementary advantages: While EXIOBASE offers a high sector resolution; the SHDB includes data of more countries. Due to the differing reference years and currencies of the two databases, a monetary exchange rate was used (see Supplementary Material section S2) in order to make the data comparable. Some calculation steps (see Social Risk Assessment section) require joint usage of both databases. A set of rules for merging the SHDB and the EXIOBASE was defined for this purpose, mainly concerning aggregation of sectors and countries, which leads to reduced sectoral detail in the EXIOBASE. A full reference table for this step is given in the Supplementary Material (section S2).

\subsection{Life Cycle Impact Assessment (LCIA)}

In the impact assessment step we deal with the classification, characterization and normalization of the three activity variables, as well as the social risk assessment (spatial social conditions) and the aggregation of the social impacts, as explained below and in Figure 2.

\section{Working Hours (WH)}

The output of this activity variable is the ratio of the work hours consumed by the product system to the total global yearly work hours supplied, which allows for a comparison with the other activity variables prior to risk assessment. It aggregates all working hours and is measured in Working Hours Points. The calculation steps are shown in Figure2A. For the normalization step, the total global yearly number of hours worked, as

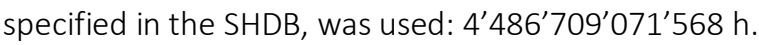

\section{Biophysical Pressure (BP)}

Similar to the previous activity variable, BP measures the ratio between the social impact of the product system and the global yearly total social impact, measured in Biophysical Pressure Points. The calculation steps are shown in Figure2B. The measuring metrics of this activity variable rely on the LCIA method ReCiPe (Goedkoop et al. 2013) and are extended by compatible characterization factors (CFs) for land and water consumption, as well as for freshwater heat pollution. For this step, all 85 substances for which emission data are available in EXIOBASE were assigned to their equivalent CFs of the original ReCiPe method. The complete list of assignments and method steps are provided in the Supplementary Material (section S3). The methodological adaptions of the ReCiPe method are schematically shown in Figure 3. All default CFs and the corresponding sources used are listed in Table 1.

\section{Added Value (AV)}

The output of the activity variable $\mathrm{AV}$ is the ratio between the added value of the product system and the total global yearly added value, given in Added Value Points. The calculation steps for Added Value are shown in Figure 2C. Since Added Value is per se a benefit, this activity variable has only negative results in the social risk assessment (i.e. Added Value Points are beneficial).

The LCI data of the EXIOBASE concerning the added value is divided into the following seven categories, which were all aggregated without any weighting for the total AV (Normalisation factor) default data input:

- Taxes less subsidies on products purchased: Total

- Other net taxes on production

- Compensation of employees: Low-skilled

- Compensation of employees: Medium-skilled

- Compensation of employees: High-skilled

- Operating surplus: Consumption of fixed capital

- Operating surplus: Remaining net operating surplus 
FIGURE 3

TABLE 1

\section{Social Risk Assessment (SRA)}

To relate the outputs of the three activity variables with the spatial social conditions in which they occur, Social Risk Factors (SRF) for each CSS were developed in the SHDB, which offers an aggregation of nearly 200 different sources of statistical data covering the topics of human rights, labour rights, governance, access to community services, and health risks (Benoit-Norris et al. 2012). A list of the 130 available risk factors is provided in the Electronic Supplementary Material. Based on the qualitative risk level data provided by the SHDB, the SRFs were calculated according to the scheme in Figure 4. SRF correspond to CF in LCA and are multiplied by activity variables to quantify potential social impacts. The default risk sets used for the SRA of each of the three activity variables are shown in Table 2 . These risks have been selected based on coverage of sectors and regions (not all risks are described everywhere, cf. Electronic Supplementary Material (XLSfile)) and suitability to assess potential social impacts of the activity variables. For an aggregated assessment, we used quantitative values to replace the qualitative risk levels of the SHDB as listed in Table 3.

\section{FIGURE 4}

\section{Final Social Impact (FSI)}

After the risk weighting of the three activity outputs, the social impacts can be aggregated to a single value, the Final Social Impact, in order to identify the most important CSS in a hotspot analysis. The default weighting of each activity variable is one (equal weights). While it is suggested to analyse the individual activity outputs, aggregation can be useful and therefore weighting might be adjusted if justified. The overall impact is measured as Final Social Impact Points (FSIP).

\section{TABLE 2}

\section{TABLE 3}

\subsection{Case studies}

In order to test the developed S-LCA method, two case studies with two different product types were conducted.

\section{T-shirt Case Study}

For this case study, we compared different types of t-shirts as a functional unit, excluding the use and disposal phase:

- $\quad$ H\&M: A t-shirt by the clothing company H\&M. It represents a cheap t-shirt bought by a clothing discounter made of cotton (5€ (Uchatius 2010; H\&M 2013)).

- HessNatur: A t-shirt by the clothing company HessNatur. It represents a more expensive t-shirt bought by a clothing company with focus on social and ecological corporate responsibility made of cotton (20€ (HessNatur 2013)). 
- $\quad$ Polyester: A t-shirt by the clothing company H\&M: It represents a cheap t-shirt bought by a clothing discounter made of synthetic fabrics $(5 €)$. For this case, only the cotton production foreground processes of the H\&M cotton t-shirt was replaced by synthetic raw material foreground processes.

Further details regarding the 7-8 foreground processes used to build the three product systems are described in the Supplementary Material (section S5).

\section{Heating System Case Study}

The following four types of home heating systems were considered with the functional unit of $1 \mathrm{kWh}$ heat supplied:

- $\quad$ Oil: Conventional heat unit for residential houses, running on oil (common oil origin country for Switzerland)

- Gas: Conventional heat unit for residential houses, running on gas (common gas origin country for Switzerland)

- Heat pump average (HP): Conventional heap pump system for residential houses, running with electricity (average electricity mix for Switzerland)

- Heat pump photovoltaic (HP PV): Conventional heap pump system for residential houses, running with electricity (electricity mix for Switzerland only considering solar energy sources)

The foreground processes which were used to build the product systems are basic and consist only of the two most elementary foreground processes for which typical costs for Switzerland are available (FWS 2009a; FWS 2009b; Erdgas Schweiz 2015):

- Construction/production of the heating system per kWh heating energy

- Necessary amount of the energy carrier per kWh heating energy

A description of the foreground system and further details can be found in the Supplementary Material (section S5).

\subsection{Sensitivity Analysis}

Sensitivity analyses of the default t-shirt product system (H\&M cotton t-shirt) were carried out to compare the default results with results using various parameter alternatives. The following parameters were considered for the sensitivity analysis:

- $\quad$ BP: ReCiPe Perspectives

- $\quad$ BP: ReCiPe Endpoint Weighting

- AV: Selection of Added Value Categories

- SRA: Quantitative Scales (linear and logarithmic options)

- SRA: Risk Sets

- $\quad$ FSI: Activity Variables Weighting

A compilation of the sensitivity analysis input parameter and results can be found in the Supplementary Material (section S4). The key results are discussed in the main paper.

\section{Results and Discussion}

The methodology is operational and allows for assessing various aspects of product systems. The results of the case studies show the applicability of the developed method and are used to discuss its limitations. The detailed results are reported in the Supplementary Material (sections S6 and S7).

\subsection{T-shirt Case Study}


The results of the t-shirt alternatives, given in FSIP, show that the HessNatur t-shirt has the highest social impact when measured using the developed S-LCIA method (Figure 5). This is an interesting result since it is expected that social impacts associated with a fair trade product would rank lower than a 'standard' product. Two main reasons cause this outcome: First, the impact of the HessNatur t-shirt is about four times that of the H\&M cotton t-shirt. However, when comparing product systems of the two clothing company's items per total monetary value ( $H \& M$ vs. HessNatur ( $5 €$ instead of $20 €)$ ), the impacts are almost equal. This means the higher price draws more impacts from respective sectors and therefore higher impacts, which is an artefact result of generic MRIO analysis. Second, while tracking back the impact of the HessNatur t-shirt, it becomes clear that the raw material production (African cotton) is the major contributor to the impacts. The CSSaverage risk factors that are applied as the default do not reflect the reality, since HessNatur assures a sustainable and socially responsible supply chain. Cotton fibres produced for HessNatur are embedded in a development aid program funded and organized mainly by HessNatur. Therefore, one might consider omitting the impacts related to cotton production, which would result in a preferable performance (Figure 5). This shows the limitation and potential of the method and data: hotspot analysis can identify potential problems, which might be analysed and reported as non-problematic as in the case of the HessNatur t-shirt, but it cannot directly address differences in standards within a CSS.

The relevance of cotton production can also be observed when comparing the cotton and polyester H\&M tshirts. The latter shows less than half of the FSIP of the cotton H\&M t-shirt and their foreground processes differ only in the raw material supply. The processing, trading and selling of cotton t-shirts do not heavily contribute to the FSIP and result in an overall social benefit through added value (and therefore a negative FSIP value), as shown in the case "HessNatur (No Cotton)" in Figure 5. Therefore it can be concluded that in order to improve the cotton T-shirt's social impact, the cotton production must be improved in terms of work conditions and environmental degradation. Additionally, this comparison shows the trade-off between social impacts: cotton is more labour intensive and has higher social risk related to working hours, while polyester production is more polluting and leads to higher social risk caused by biophysical pressures.

Finally, the case study illustrates the limitations of the available databases, since the level of distinction is not enough to assess the different quality of industries within the same CSS. Therefore, this aspect should be kept in mind when analysing hotspots of products at different price levels, as described above for the HessNatur case.

FIGURE 5

\subsection{Heating System Case Study}

The analysis of the heating systems shows that the oil heating system has by far the highest social impact (Figure 6). Nevertheless, its FSIP remains marginally negative (positive effect), which is a consequence of the equal aggregation of the three activity variables. The largest negative effect (BP and WH) of the oil heating system is derived from the Water transport sector, which represents the shipping transport of the oil from the oil production origin to the use countries (see Figure 7C). More specifically, this is attributed to sea and coastal transport (Figure 8B). This is caused by the high emissions of sea transport (Supporting Information), which could be partially excluded from the social assessment since it mainly affects unpopulated areas (i.e. the oceans). Another surprisingly large BP impact comes from the Crops nec sector ("crops not else classified", which can be any crop not separately reported in statistics) (Figure 7C), since it is difficult to explain how this sector contributes to an oil heating system. This is also the case for gas production. This effect is caused by the underlying MRIO databases and partially related to the limited sector and regional resolution in the MRIO databases, which means that more generic sectors in the supply chain involve a broad range of other sectors. 
The two above mentioned phenomena (impact of water transport and crop nec) are also realized when considering the surprisingly high BP value of the heat pump system running on energy from photovoltaic cells (HP PV). Figure 7B shows that the CSS Africa Crops nec and Switzerland Water transport are dominating the BP impact of this heating system. Tracking back the BP impact to the midpoint shares shows that major contributions are derived from Human Toxicity, Particulate Matter Formation and Land Use. The first two midpoint shares are mostly due to sea and coastal transport in Europe (e.g. for transport of supply material for the heating system), which might be excluded as discussed above, and electricity production by coal in China and India (e.g. for production of supply products for the heating system). Land Use appears to have its main shares, similar to the oil heating system (Figure 8C), in crop sectors in Africa, Asia and Latin America (potentially for biofuel used in the supply chains).

The big impact of the Swiss electricity and machinery sectors on AV and WH is expected since the investigated heating system (HP PV) is located, maintained and produced in Switzerland. This causes relatively low $\mathrm{WH}$ risks and high benefits of $\mathrm{AV}$, therefore no dominating problematic hotspot is identified. As shown in Figure 7F, the impacts are unevenly distributed: while benefits occur mainly in Switzerland and Germany, Africa, China, Asia Pacific and India bear a high share of impacts and experience no significant benefits from AV. A similar picture is found for oil (Figure 7E), where Asia Pacific, Africa, China and Latin America show a high negative to positive effect ratio. In terms of impacts on the activity variables WH and BP (Figure 8B,D), a more detailed trade-off can be seen with Added Value origins (Figure 8B), showing that the oil sourcing and processing are the hotspots, while the consuming region mainly generates added value benefits.

FIGURE 6

FIGURE 7

FIGURE 8

\subsection{Sensitivity Analysis}

None of the examined parameters (see Methods section) was found to have an extraordinarily high impact on the FSI of the product system (see Supplementary Material section S4). As shown in Figure 5, the FSI value of the H\&M (cotton) t-shirt is 5.9E-13 FSIP, while the absolute deviation value is about a factor of 2 (maximal positive FSI: +1,2E-12 FSIP and maximal negative FSI: -5,3E-14 FSIP), which is considered relatively low in a hotspot assessment.

The biggest differences between the alternatives occurred in the comparison of the Activity Variable Weighting (BP:WH:AV). However, this is a subjective value judgement, and therefore it is recommended to vary this value in the assessment and interpret activity variables independently, as we presented in the oil boiler case study (Figure 8). Additionally, presenting single score results is also debated in LCA (even not allowed for public reporting within the rules of ISO 2006, ISO 2006), and therefore more detailed assessments as shown in section 3.2 are suggested.

The element with the second largest sensitivity is the relation of qualitative risk levels to numbers. There is a strong effect from choosing either a linear (default) or logarithmic scale, since in the latter case risks get a higher weight compared to the inventory results before SRA. Since this step is needed for assessing the individual activity variables in a quantitative way, it is of higher importance than the weighting step and therefore sensitivity assessment is strongly recommended. Here the values ranged from 4.2E-13 FSIP to 1.2E12 FSIP for the H\&M cotton t-shirt. Since the ratio between the scaling alternatives stayed the same in the highest levels of aggregation (AV, WH, BP level as well as midpoint and AV category level) it is mainly important for identifying hotspots within one activity variable.

\subsection{Limitations}


The applicability of the developed S-LCA method was shown in the case study section, but several limitations have been revealed. A general, crucial constraint is caused by the usage of MRIO databases. The underlying assumptions and approximations, as well as the provided sectoral and regional resolutions, bring inaccuracy into the comparative assessments and challenge the case specificity (e.g. HessNatur case study). Additionally, since the CSS are broad sectors, the supply chain includes many different inputs which cannot be fully separated in the foreground modelling. As an example, the retail sector contains supply chain impacts that might be used for business activities, but also others that are related to the production of the sold products (and therefore modelled specifically in the foreground system). However, this is an intrinsic problem of MRIO based LCA and not specific to our approach.

For detailed case studies, although difficult, risks should be analysed in detail for the identified hotspots: ethically loaded topics (e.g. forced labour) will not likely be documented by the responsible instance (e.g. the chief of a production site), however this person might be the only one with sufficient access to information about local conditions. As is shown in the t-shirt case, it can be discussed how labels or best-in-class producers can be excused from some of the estimated damages. However, this must be reported and supported by additional references.

Through the introduction of the two additional activity variables (AV and BP) three extra stakeholder groups, suggested by GSLCA (Local Community, Society and Value Chain Actor), were included. This brings major progress with regard to the stakeholder representation of social impacts. However, the fifth suggested stakeholder group (Consumer) could not be involved. Since the consumer is responsible for the damage and is benefiting from the product or service, this limitation might be less important for addressing external effects. Benefits or impacts from the service or product itself (i.e. the functional unit) is typically not addressed yet in S-LCA (UNEP/SETAC 2009).

For all stakeholder groups, it has to be noted that our quantitative analysis of global supply chains cannot address the stakeholder groups in appropriate detail as requested from social science. Stakeholder assessments need to be done on a local level and cannot be replaced by S-LCA, in the same way as LCA cannot replace environmental impact assessments.

The various assumptions and methodological choices clarified in the Methods section lead to high uncertainties. Since the underlying data sources do not provide appropriate uncertainty information, for this purpose we conducted a sensitivity analysis. However, we could not account for the underlying uncertainties of the SHDB, Exiobase and the impact assessment methods. In any case, when conducting an IO-LCA we have to note that such assessments detect hotspots rather than reliable case-specific quantitative impacts as mentioned above.

\subsection{Outlook}

The limitations induced by using MRIO data could be reduced by better product representation in the sectors. This could be implemented by hybrid approaches combining process LCA and MRIO data.

Additionally, risk values for product-specific attributes such as labels (e.g. fair trade) or best-of-industry certificates could be added to the database. Another improvement for individual case studies could be reached through distinguishing between impacts from foreground and background CSS. Such an assessment can guide the analyst to determine the boundaries of the foreground system as a function of total impacts.

In future research, additional details of the supply chain could be revealed by applying structural path analysis (Acquaye et al. 2011) on the presented data and method. This would allow one to backtrack from which specific supply path an impact occurs and might clarify unexpected results (e.g. why crops from Africa play a significant role in gas and oil provision).

The presented method provides new insights and can be complemented by implementing other promising approaches using different MRIO databases, such as the inequality footprint of nations (Alsamawi et al. 2015). Also, the results of WH impacts could be enhanced by combining it with results by Simas et al. (2015), which use labour data for Exiobase. By using different underlying data sources and approaches, the results can become more robust. 


\section{Conclusions}

The presented S-LCA method brings some valuable improvements by including not only working hours but additional aspects of social concerns as well as stakeholder groups affected. The inclusion of these two additional activity variables provides several enhancements: First, the dimension of positive impacts measured in an S-LCA is introduced (AV variable). As such, this refers to the social effects of added value and not economic sustainability. Second, the affected stakeholder groups are more completely represented (BP and AV variable), since not only work related, but also indirect impacts due to degradation of environment and increased income as well as tax expenses, are covered. These two changes can clearly be observed when comparing the total social impacts (FSI) with the social impacts measured only by the assigned working hours (WH) of the discussed case studies. However, it is highly important to consider the three dimensions separately, since generally different stakeholders are affected by the three dimensions covered. The FSI cannot be used to support net benefits, it should be considered as a way to reduce the dimensions only for interpretation purposes.

Third, our approach exhibits a comprehensive perspective in the direction of LCSA (Life Cycle Sustainability Assessment): AV and BP partially cover the environmental and economic dimension. Potentially this method can be expanded to include all three pillars of sustainability in a more comprehensive way. It directly shows which CSS in a product system have high social and environmental impacts in comparison with generated added value, and therefore allows for assessing unequal exchanges, as illustrated for the oil heating system. Nonetheless, it needs be pointed out here that in any result interpretation the potential of double counting some impacts should be considered carefully.

Finally, there is a note of caution regarding the lack of detail in the MRIO database and therefore in the representation of the product systems, as stated in our case studies. However, the current assessment is a valuable method to identify hotspots that require a potential adjustment of risk factors, as discussed for certified cotton production. It cannot replace detailed social assessments, including a multitude of local effects that cannot be captured in global quantitative models. Therefore, the results cannot be used for product labelling nor purely quantitative product comparison. Future research towards combining MRIO and process based databases are therefore required for improving both social LCA and LCSA.

\section{Acknowledgement}

We thank Andreas Ciroth and GreenDelta GmbH for their input on S-LCA as well as for valuable comments on the approach developed, and Catherine Benoit for sharing additional information on the SHDB. We acknowledge Stefanie Hellweg and Christie Walker for proofreading the manuscript. This work was partially sponsored by the Swiss National Science Foundation through the project "Sustainability evaluation of biorefinery systems for fuel and commodity chemical generation from plant residues". 


\section{References}

Acquaye, AA, Wiedmann T, Feng K, Crawford RH, Barrett J, Kuylenstierna J, Duffy AP, Koh SCL, McQueenMason S (2011) Identification of 'Carbon Hot-Spots' and Quantification of GHG Intensities in the Biodiesel Supply Chain Using Hybrid LCA and Structural Path Analysis. Environ Sci Technol 45(6): 2471 2478.

Alsamawi A, Murray J, Lenzen M, Moran D, Kanemoto K (2014) The Inequality Footprints of Nations: A Novel Approach to Quantitative Accounting of Income Inequality. PLoS ONE 9(10): e110881. doi:10.1371/journal.pone.0110881

Benoît Norris C (2014) Data for social LCA. Int J Life Cycle Assess 19:261-265. doi: 10.1007/s11367-013-06447

Benoît-Norris C (2012) 20. Social Life Cycle Assessment : A Technique Providing a New Wealth of Information to Inform Decision Making. Life Cycle Assess Handb A Guid Environ Sustain Prod 1996:433-452.

Benoit-Norris C, Cavan DA, Norris G (2012) Identifying social impacts in product supply chains: Overview and application of the social hotspot database. Sustainability 4:1946-1965. doi: 10.3390/su4091946

Blok, K., Huijbregts, M., Roes, L., Haaster, B. van, Patel, M., Hertwich, E., Wood, R., Hauschild, M.Z., Sellke, P., Antunes, P., Hellweg, S., Ciroth, A., Harmelink, M., 2013. A Novel Methodology for the Sustainability Impact Assessment of New Technologies. Report prepared within the EC 7th framework project PROSUITE. Available at: www.prosuite.org

Brundtland GH (1987) Our Common Future: Report of the World Commission on Environment and Development. Med Confl Surviv 4:300. doi: 10.1080/07488008808408783

Bryman A (2012) Social Research Methods. New York: Oxford University Press.

Chhipi-Shrestha GK, Hewage K, Sadiq R (2015) “Socializing" sustainability: a critical review on current development status of social life cycle impact assessment method. Clean Technol Environ Policy 17:579-596. doi: 10.1007/s10098-014-0841-5

Dreyer LC, Hauschild MZ, Schierbeck J (2006) Societal Assessment ( Subject Editor : David Hunkeler ) A Framework for Social Life Cycle Impact Assessment. Int J LCA 11:88-97. doi: 10.1065/lca2005.08.223

Erdgas Schweiz (2015) Kostenvergleich verschiedener Heizsysteme. https://www.erdgas.ch/fileadmin/customer/erdgasch/Data/Erdgas/Preise/kostenvergleich_d.pdf.

Flick U (2008) Triangulation - Eine Einführung. Verlag für Sozialwissenschaften

FWS (2009a) Heizkostenvergleich Mehrfamilienhaus. In: Fachverein Wärmepumpen Schweiz Website. www.fws.ch/tl_files/download_d/Downloads/heizkostenvergleich_mfh_april2009_d.xls?phpMyAdmin= 6b841e574b7e027ebeb2ac08849f32af.

FWS (2009b) Heizkostenvergleich Einfamilienhaus. In: Fachverein Wärmepumpen Schweiz Website. www.fws.ch/tl_files/download_d/Downloads/kopie_von_heizkostenvergleich_efh_april2009_d_2_.xls ?phpMyAdmin=6b841e574b7e027ebeb2ac08849f32af.

Gaasbeek A, Meijer E (2013) Handbook on a Novel Methodology for the Sustainability Impact Assessment of New Technologies.

Goedkoop M, Heijungs R, De Schryver A, et al (2013) ReCiPe 2008. A LCIA method which comprises harmonised category indicators at the midpoint and the endpoint level.. doi: http://www.lcia-recipe.net

H\&M (2013) H\&M Annual Report 2013.

http://about.hm.com/content/dam/hm/about/documents/en/Annual Report/Annual-Report2013_en.pdf (Accessed 06.04.2015).

Haas A, Pfister S, Zimdars C (2017). Social LCA Data in a Tool v1. Mendeley Data; https://doi.org/10.17632/885knh8s4j.1

HessNatur (2013) Hessnatur Bericht zur Nachhaltigkeit. 
Hicks, C. C., Levine, A., Agrawal, A., Basurto, X., Breslow, S. J., Carothers, C., ... Levin, P. S. (2016). Engage key social c§oncepts for sustainability. Science, 352(6281), 38-40. Retrieved from http://science.sciencemag.org/content/352/6281/38.abstract

ISO (2006) ISO14040:environmental managements-lifecycleassessments-principles and framework. International Organization for Standardization, Geneva.

Jørgensen A (2013) Social LCA - A way ahead? Int J Life Cycle Assess 18:296-299. doi: 10.1007/s11367-0120517-5

Klöpffer W, Grahl B (2014) Life Cycle Assessment (LCA): A Guide to Best Practice. Wiley-VCH, Weinheim

Martinez-Blanco J, Lehmann A, Chang YJ, Finkbeiner M (2015) Social organizational LCA (SOLCA) - a new approach for implementing social LCA. Int J Life Cycle Assess 20:1586-1599. doi: 10.1007/s11367-0150960-1

Mattioda RA, Mazzi A, Canciglieri O, Scipioni A (2015) Determining the principal references of the social life cycle assessment of products. Int J Life Cycle Assess 1155-1165. doi: 10.1007/s11367-015-0873-z

McKinney W (2015) Pandas data analysis library.

Ness B, Urbel-piirsalu E, Anderberg S, Olsson L (2006) Categorising tools for sustainability assessment. Ecol Econ. doi: 10.1016/j.ecolecon.2006.07.023

Norris G a (2006) Social Impacts in Product Life Cycles Towards Life Cycle Attribute Assessment. Harvard Sch Public Heal 1:97-104. doi: 10.1065/lca2006.04.017

Pfister S, Curran M, Koehler A, Hellweg S (2010) Trade-offs between land and water use: regionalized impacts of energy crops.

Pfister S, Saner D, Koehler A (2011) The environmental relevance of freshwater consumption in global power production. Int J Life Cycle Assess 16:580-591. doi: 10.1007/s11367-011-0284-8

Simas M, Wood R, Hertwich E (2015) Labor Embodied in Trade. J Ind Ecol 19(3): 343-356

Uchatius W (2010) Das Welthemd. Der Modekonzern H\&M tritt gegen Ausbeutung ein. Und doch verkauft er Kleider für ein paar Euro. Wie kann das sein? In: Die Zeit Online. http://www.zeit.de/2010/51 /Billige-TShirts (Accessed 06.04.2015).

UNEP/SETAC (2009) Guidelines for Social Life Cycle Assessment of Products.

United Nations (1993) Agenda 21. The United Nations Programme of Action from Rio. United Nations, New York, USA.

Valdivia S, Ugaya CML, Hildenbrand J, et al (2013) A UNEP/SETAC approach towards a life cycle sustainability assessment - Our contribution to Rio+20. Int J Life Cycle Assess 18:1673-1685. doi: 10.1007/s11367012-0529-1

Verones F, Hanafiah MM, Pfister S, et al (2010) Characterization factors for thermal pollution in freshwater aquatic environments. Environ Sci Technol 44:9364-9369. doi: 10.1021/es102260c

Weidema B (2006) The Integration of Economic and Social Aspects in Life Cycle Impact Assessment. Int J Life Cycle Assess 11:89-96. doi: 10.1065/lca2006.04.016

Wood R, Stadler K, Bulavskaya T, et al (2015) Global sustainability accounting-developing EXIOBASE for multiregional footprint analysis. Sustain 7:138-163. doi: 10.3390/su7010138

WRI (2005) Millennium Ecosystem Assessment, Ecosystems and Human Well-Being: Biodiversity Synthesis. World Resources Institute, Washington, DC

Wu R, Yang D, Chen J, et al (2014) Social Life Cycle Assessment Revisited. Sustainability 6:4200-4226. doi: $10.3390 /$ su 6074200 
Table 1: Used default values for the Biophysical Pressure calculation steps.

\begin{tabular}{|c|c|}
\hline Calculation step & Default values \\
\hline $\begin{array}{cl}\text { ReCiPe Midpoint characterization factors: } \\
\text { - } & \text { Particulate matter formation } \\
\text { - } & \text { Human toxicity } \\
\text { - } & \text { Freshwater aquatic ecotoxicity } \\
\text { - } & \text { Terrestrial ecotoxicity } \\
\text { - } & \text { Photochemical oxidation } \\
\text { - } & \text { Acidification } \\
\text { - } & \text { Eutrophication }\end{array}$ & $\begin{array}{l}\text { Factors of the Hierarchist perspective with the } \\
\text { related spatial resolution (global) provided by the } \\
\text { ReCiPe method (Goedkoop et al. 2013) were } \\
\text { chosen. }\end{array}$ \\
\hline ReCiPe related Midpoint "Water use" & $\begin{array}{l}\text { The summed amount of Water consumption blue } \\
\text { provided by the EXIOBASE on a country resolution } \\
\text { level was used ( } \mathrm{m}^{3} / € \text { ) for midpoint assessment } \\
\text { (Pfister et al. 2011). }\end{array}$ \\
\hline $\begin{array}{l}\text { ReCiPe related Midpoint "Land use" (Pfister et al. } \\
\text { 2010) }\end{array}$ & $\begin{array}{l}\text { All available land use data in the EXIOBASE were } \\
\text { used on a country resolution level }\left(\mathrm{km}^{2} / €\right) \text {. An } \\
\text { adjustment factor for the land use types according } \\
\text { to the following list was used for midpoint } \\
\text { assessment (Pfister et al. } 2010) \text { : } \\
\text { - } \quad \text { Arable land use: } 0.99 \\
\text { - Pasture land use: } 0.91 \\
\text { - } \quad \text { Forest land use: } 0.40\end{array}$ \\
\hline $\begin{array}{l}\text { ReCiPe related Midpoint "Heat rejected to } \\
\text { freshwater" }\end{array}$ & $\begin{array}{l}\text { The summed amount of Heat rejected to } \\
\text { freshwater by the EXIOBASE was used (TJ/€) for } \\
\text { midpoint assessment (Verones et al. 2010). }\end{array}$ \\
\hline Endpoint characterization factors & $\begin{array}{l}\text { Factors of the Hierarchist perspective by the ReCiPe } \\
\text { method (Goedkoop et al. 2013) and the ReCiPe } \\
\text { related sources (Pfister et al. 2010; Verones et al. } \\
\text { 2010; Pfister et al. 2011) with the provided spatial } \\
\text { resolution was chosen. }\end{array}$ \\
\hline Endpoint normalization factors & $\begin{array}{l}\text { The global yearly values of the two endpoints are } \\
\text { calculated and used as normalization reference. } \\
\text { Only values of the Midpoint selection of this } \\
\text { method were considered (see Figure 3). }\end{array}$ \\
\hline Endpoint weighting & $\begin{array}{l}\text { The default weighting ratio of the two Endpoints is } \\
0.5: 0.5 \text {. }\end{array}$ \\
\hline
\end{tabular}


Table 2: Default risk sets used for the calculation of the SR factors of the three activity variables, based on risks in the SHDB (Benoit-Norris 2014).

\begin{tabular}{|c|c|}
\hline Working Hours & Relation to Work Issues \\
\hline Characterization of Cingranelli-Richards Human Rights Dataset-indicator1 & Worker rights \\
\hline Overall Risk of fragility in the legal system & Worker rights \\
\hline Overall Risk of Gender Inequality in country & Worker income \\
\hline Overall Risk of loss of life years by exposure to carcinogens in occupation & Worker health \\
\hline Risk of Child Labor in sector, Total (qualitative) & Worker rights/health \\
\hline Risk of excessive working time by sector & Worker health \\
\hline Risk of fatal injury by sector & Worker health \\
\hline Risk of Forced Labor by Sector & Worker health/right \\
\hline Risk of loss of life years by airborne particulates in occupation & Worker health \\
\hline Risk of Wages being under $\$ 2$ per day & Worker income \\
\hline Risk that a country lacks or does not enforce Freedom of Association rights & Worker rights \\
\hline Risk that Country does not provide adequate labor laws by Sector & Worker rights \\
\hline Risk that indigenous people are negatively impacted at sector level & Worker rights \\
\hline Biophysical Pressure & Relation to Environmental Issues \\
\hline Overall Risk of fragility in the legal system & Community protection \\
\hline Overall Risk of loss of life years by exposure to carcinogens in occupation & Community protection \\
\hline Risk of Mortality from Communicable Diseases & $\begin{array}{l}\text { Community } \\
\text { protection/resilience }\end{array}$ \\
\hline Risk of no access to an Improved Source of Drinking Water-total & Community resilience \\
\hline Risk of no access to an Improved source of Sanitation-total & Community resilience \\
\hline Risk that Population may be affected by natural disasters & Community resilience \\
\hline Risk that there are too few hospital beds to support population & Community protection \\
\hline Added Value & Relation to Economic Issues \\
\hline Overall Risk of inadequate social benefits & Tax distribution \\
\hline Overall Risk of fragility in the legal system & Tax distribution \\
\hline Overall Risk of loss of life years by exposure to carcinogens in occupation & Income risks \\
\hline Risk that a country lacks or does not enforce Collective Bargaining rights & Income risks \\
\hline Risk that a country lacks or does not enforce Freedom of Association rights & Income risks \\
\hline Risk that a country lacks or does not enforce the Right to Strike & Income risks \\
\hline Risk that a country ranks poorly for corruption perception & Tax distribution \\
\hline $\begin{array}{l}\text { Risk that a country ranks poorly on the World Bank Worldwide Governance } \\
\text { Indicator's Corruption Index }\end{array}$ & Tax distribution \\
\hline Risk that Country does not ratify ILO conventions by Sector & Income risks \\
\hline
\end{tabular}


Table 3: Default assignment of quantitative values to the qualitative risk level in the SHDB for the three activity variables with a linear scale.

\begin{tabular}{lcc}
\hline $\begin{array}{c}\text { Qualitative risk level } \\
\text { (SHDB) }\end{array}$ & $\begin{array}{c}\text { Quantitative value for working hours } \\
\text { and biophysical pressure }\end{array}$ & $\begin{array}{c}\text { Quantitative value for } \\
\text { added value }\end{array}$ \\
\hline Not applicable & 0 & 0 \\
\hline Low risk & 1 & -4 \\
\hline Medium risk & 2 & -3 \\
\hline High risk & 3 & -2 \\
\hline Very high risk & 4 & -1 \\
\hline No data & 2.5 & -2.5 \\
\hline
\end{tabular}




\title{
Enhancing comprehensive measurement of social impacts in S-LCA by including environmental and economic aspects
}

\author{
Christopher Zimdars ${ }^{1} \cdot$ Adrian Haas $^{1} \cdot$ Stephan Pfister ${ }^{1} \bowtie$ \\ Institute of Environmental Engineering, Chair of Ecological System Design, ETH Zurich, 8039 Zurich, \\ Switzerland \\ $\bowtie$ Stephan Pfister, Email: pfister@ifu.baug.ethz.ch
}

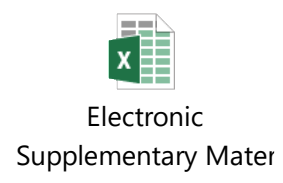

\section{List of Figures}

Figure S1: Schema of database merging rules. Dotted arrows indicate country aggregation form SHDB to EXIOBASE, while the solid lines indicate sector aggregation from EXIOBASE to SHDB.

Figure S1: Schema of database merging rules. Dotted arrows indicate country aggregation form SHDB to EXIOBASE, while the solid lines indicate sector aggregation from EXIOBASE to SHDB.

Figure S2: Final Social Impacts of sensitivity analysis of the considered calculation steps for the default case

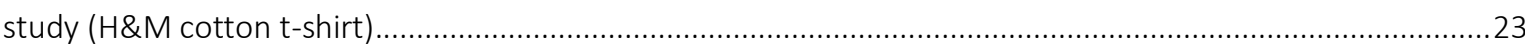

Figure S 3: FSI, BP, WH and AV of the quantitative value scaling variations of the default product system. ....24

Figure S4: BP of the three t-shirt alternatives divided into the midpoint shares...........................................22

Figure S5: AV of the three t-shirt alternatives divided into the Added Value category shares...........................30

Figure S6: Ten most contributing CSS of the HessNatur t-shirt (20€) FSI divided into the activity variable

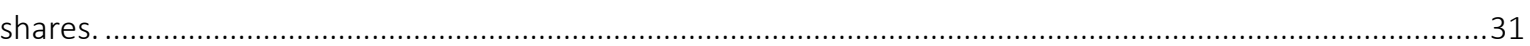

Figure S7: BP of the four heating system alternatives divided into the midpoint shares. .................................32

Figure S8: AV of the four heating system alternatives divided into the Added Value category shares. .............33

Figure S9: Emissions of most polluting substances in the sector "sea and coastal water transport" for all the

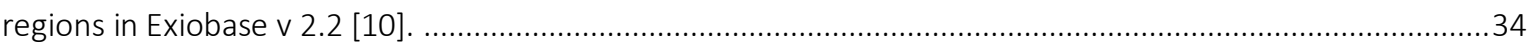

\section{List of Tables}

Table S1: Default values and alternatives use in the sensitivity analysis for the considered calculation steps. 21 Table S2: H\&M (Cotton) t-shirt foreground processes and corresponding CSS in EXIOBASE and SHDB

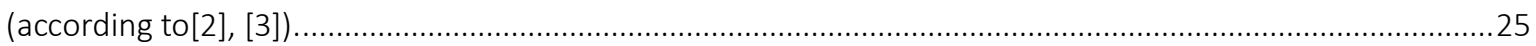
Table S3: Polyester (H\&M) t-shirt foreground processes and corresponding CSS in EXIOBASE and SHDB

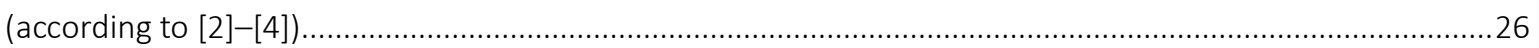
Table S4: HessNatur t-shirt foreground processes and corresponding CSS in EXIOBASE and SHDB (according to

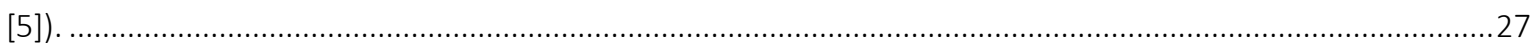
Table S5: Heating systems foreground processes and corresponding CSS in EXIOBASE and SHDB (according to [6]-[9] and information in the Electronic Supplementary Material). 


\section{S1. Framework life cycle sustainability assessment (LCSA) and social LCA (S-LCA)}

The relation of S-LCA and LCSA with LCA and economic assessments is depicted in Figure S1.

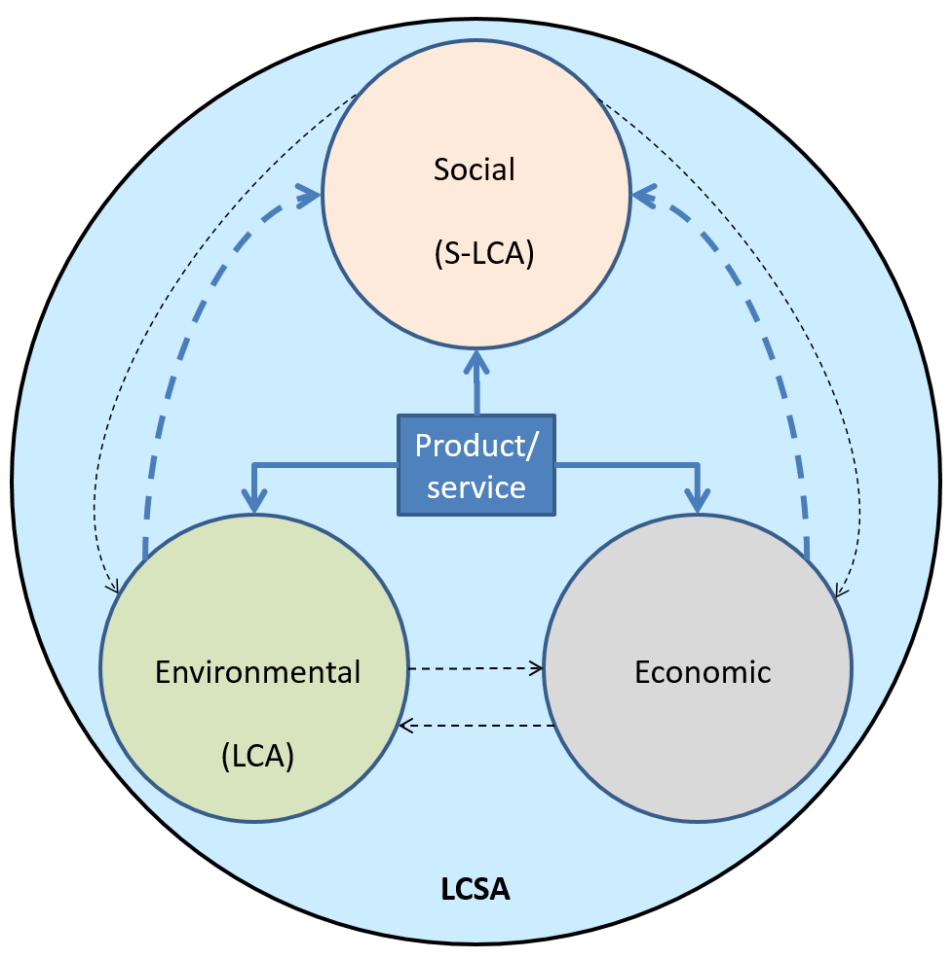

Figure S1: LCSA includes three pillars: social, economic and environmental sustainability. The product system has direct links to the three pillars and also indirect effects between them (dashed arrows). The effects considered in this work are presented by bold arrows.

\section{S2. Database Merging Description (supporting LCl section)}

The dimension mismatch and the rules for merging are illustrated in Figure S2. To match the SHDB's country resolution to those of the Exiobase, the surplus countries are grouped into the 5 rest of world regions (RoW), see the dotted arrows in Figure S2. The opposite transformation (i.e. disaggregation of RoW regions) is not used.

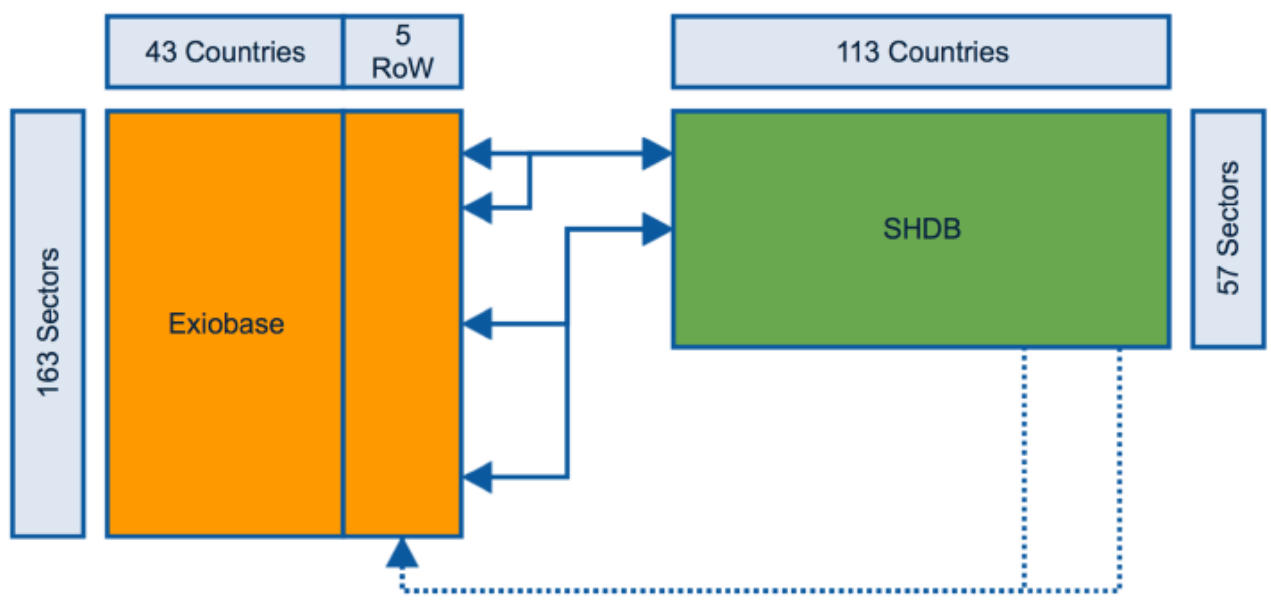

Figure S2: Schema of database merging rules. Dotted arrows indicate country aggregation form SHDB to EXIOBASE, while the solid lines indicate sector aggregation from EXIOBASE to SHDB. 
The merging of the industry sector data is based on the concept that multiple Exiobase sectors can be grouped together to the corresponding SHDB sector. For example 15 sectors related to electricity production and distribution in the Exiobase ("Production of electricity by coal", "Production of electricity by hydro", "Distribution and trade of electricity", etc.) are assigned to a single sector "Electricity" of the SHDB. This means all these Exiobase sectors have the same risks level. All sectors combined comprise the whole economy of a country in both databases. A full list of sector and country matches can be found in the Electronic Supplementary Material (sections "Country Match" and "Sector Match").

The following exchange rate was used for currency merging of the two databases from US Dollars to Euro: $0.79 \$ / €$. This is the average exchange rate of the years 2004-2007 (reference years for the two databases [1]).

\section{S3. Biophysical Pressure Calculation Steps Description}

As mentioned in the BP section the activity variable Biophysical Pressure was chosen to better represent the S-LCA stakeholder groups "Local Community" and "National Society". To include only characterization factors (CF), which really affect the stakeholder groups and their embedding natural environment in a direct or indirect way, the set of midpoint CFs of the ReCiPe method was adapted as shown in the following list:

- Particulate matter formation

- Human toxicity

- Freshwater aquatic ecotoxicity

- Terrestrial ecotoxicity

- Photochemical oxidation

- Acidification

- Eutrophication

- Water use

- Land use

- Heat rejected to freshwater

The endpoint results (calculated according to the ReCiPe endpoint method) are normalized and weighted to receive the activity variable Biophysical Pressure. With default settings the global yearly values of the two endpoints "Human Health" and "Ecosystem Quality" are calculated and used as reference. This means that only the values of the total yearly damages caused by the impact categories showed for midpoint CF in the above list is used for normalization. This ensures that the biophysical pressure is comparable to the other activity variables. The assignment of the 85 substances available in the EXIOBASE to its equivalent in the original ReCiPe method can be found in the Electronic Supplementary Material (section "ReCiPe Substance Assignement"). 


\section{S4. Sensitivity Analysis}

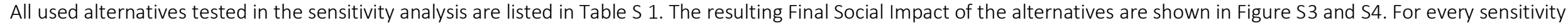
analysis only the investigated parameter was adjusted from the default case (H\&M cotton t-shirt, see Table S2).

Table S1: Default values and alternatives use in the sensitivity analysis for the considered calculation steps.

\begin{tabular}{|c|c|c|c|c|}
\hline Calculation Step & Default Approach & 1 Alternative & 2. Alternative & 3. Alternative \\
\hline BP: ReCiPe Perspectives & Hierarchist & Individualist & Egalitarian & \\
\hline $\begin{array}{l}\text { BP: ReCiPe Endpoint } \\
\text { Weighting }\end{array}$ & $\begin{array}{l}\text { - Human Health: } 0.5 \\
\text { - Ecosystem Quality: } 0.5\end{array}$ & $\begin{array}{l}\text { - Human Health: } 0.9 \\
\text { - Ecosystem Quality: } 0.1\end{array}$ & $\begin{array}{l}\text { - Human Health: } 0.99 \\
\text { - Ecosystem Quality: } 0.01\end{array}$ & \\
\hline $\begin{array}{l}\text { AV: Selection of Added } \\
\text { Value Categories }\end{array}$ & $\begin{array}{l}\text { All categories: } \\
\text { - Taxes less subsidies on products } \\
\text { purchased: Total } \\
\text { - Other net taxes on production } \\
\text { - Compensation of employees: Low- } \\
\text { skilled } \\
\text { - Compensation of employees: Medium- } \\
\text { skilled } \\
\text { - Compensation of employees: High- } \\
\text { skilled } \\
\text { - Operating surplus: Consumption of } \\
\text { fixed capital } \\
\text { - Operating surplus: Remaining net } \\
\text { operating surplus }\end{array}$ & $\begin{array}{l}\text { Only taxes related categories: } \\
\text { - Taxes less subsidies on products } \\
\text { purchased: Total } \\
\text { - Other net taxes on production }\end{array}$ & $\begin{array}{l}\text { Only compensation related } \\
\text { categories: } \\
\text { - Compensation of } \\
\text { employees: Low-skilled } \\
\text { - Compensation of } \\
\text { employees: Medium- } \\
\text { skilled } \\
\text { - Compensation of } \\
\text { employees: High-skilled }\end{array}$ & $\begin{array}{l}\text { Only operating } \\
\text { surplus related } \\
\text { categories: } \\
\text { - Operating surplus: } \\
\text { Consumption of } \\
\text { fixed capital } \\
\text { - Operating surplus: } \\
\text { Remaining net } \\
\text { operating surplus }\end{array}$ \\
\hline SRA: Quantitative Scales & $\begin{array}{l}\text { Linear Scale: } \\
\text { - Not applicable: } 0 \\
\text { - Low risk: } 1 \\
\text { - Medium risk: } 2 \\
\text { - High risk: } 3 \\
\text { - Very high Risk: } 4 \\
\text { - No data: } 2.5^{1}\end{array}$ & $\begin{array}{l}\text { 2× Scale (Base2): } \\
\text { - Not applicable: } 0 \\
\text { - Low risk: } 1 \\
\text { - Medium risk: } 2 \\
\text { - High risk: } 4 \\
\text { - Very high risk: } 8 \\
\text { - No data: } 3.75^{1}\end{array}$ & $\begin{array}{l}\text { 10× Scale (Base10): } \\
\text { - Not applicable: } 0 \\
\text { - Low risk: } 1 \\
\text { - Medium risk: } 10 \\
\text { - High risk: } 100 \\
\text { - Very high risk: } 1000 \\
\text { - No data: } 277,75^{1}\end{array}$ & No SRA \\
\hline
\end{tabular}




\begin{tabular}{|c|c|c|c|}
\hline SRA: Risk Sets & $\begin{array}{l}\text { Narrow risk set: } 7-13 \text { risk factors with } \\
\text { expected direct influence on the activity } \\
\text { variables (For more detailed Information, } \\
\text { see Electronic Supplementary Material) }\end{array}$ & $\begin{array}{l}\text { Broader risk set: } \\
32-38 \text { risk factors with expected } \\
\text { direct and indirect influence on } \\
\text { the activity variables (For more } \\
\text { detailed Information, see } \\
\text { Electronic Supplementary } \\
\text { Material) }\end{array}$ & No SRA \\
\hline $\begin{array}{l}\text { FSI: Activity Variables } \\
\text { Weighting }\end{array}$ & $\begin{array}{l}\text { Equal Weighing of activity variables } \\
(1: 1: 1)\end{array}$ & \multicolumn{2}{|c|}{$\begin{array}{l}\text { Various alternatives (Biophysical Pressure : Working Hours : Added Value): } \\
\quad-4: 4: 2 \\
\quad-10: 1: 1 \\
\quad-1: 10: 1 \\
-1: 1: 10 \\
\quad-10: 10: 1\end{array}$} \\
\hline
\end{tabular}

${ }^{1}$ The "No Data" value was calculated as average of values of low risk, medium risk, high risk and very high risk. 


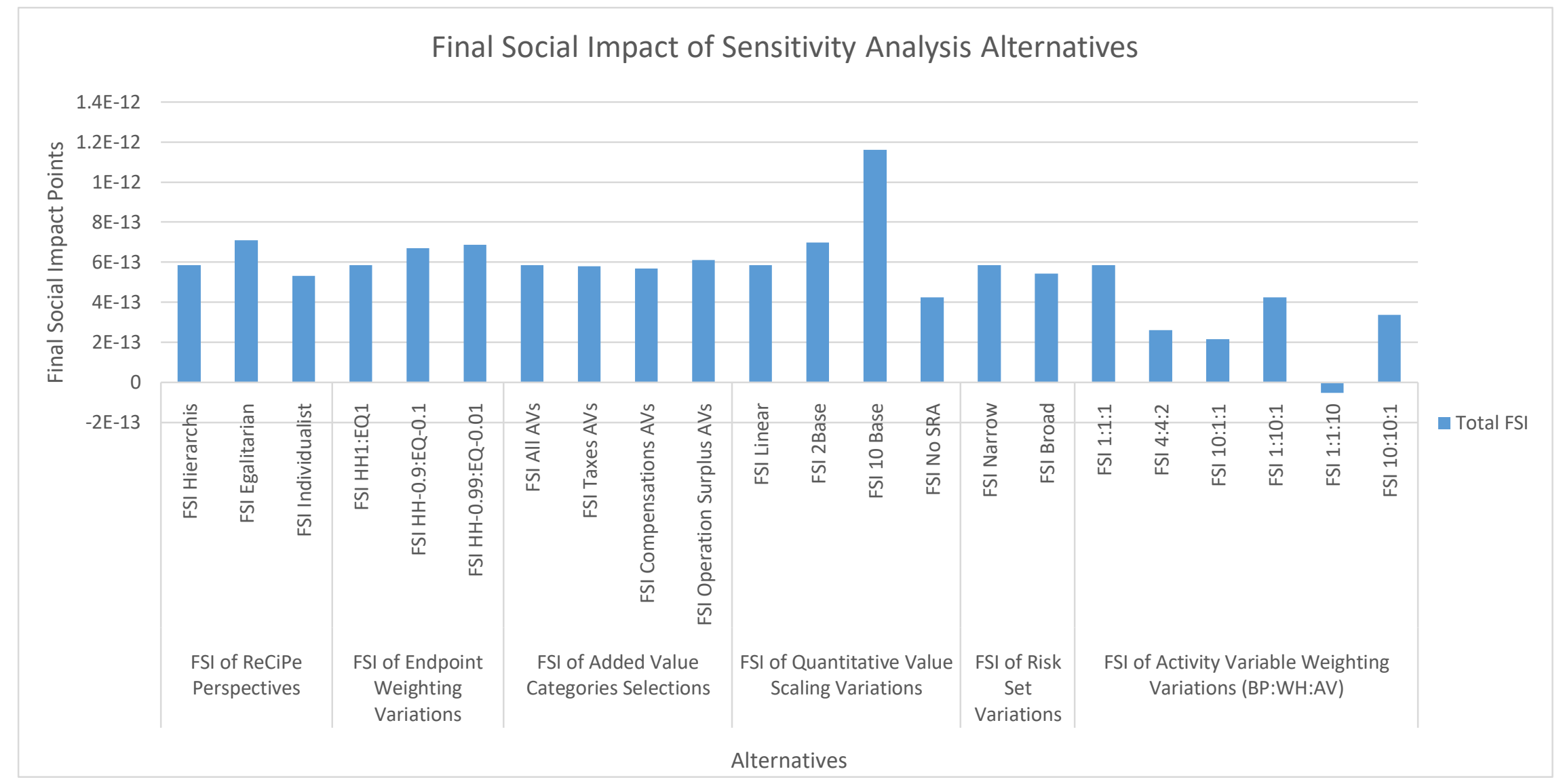

Figure S3: Final Social Impacts of sensitivity analysis of the considered calculation steps for the default case study (H\&M cotton t-shirt). 


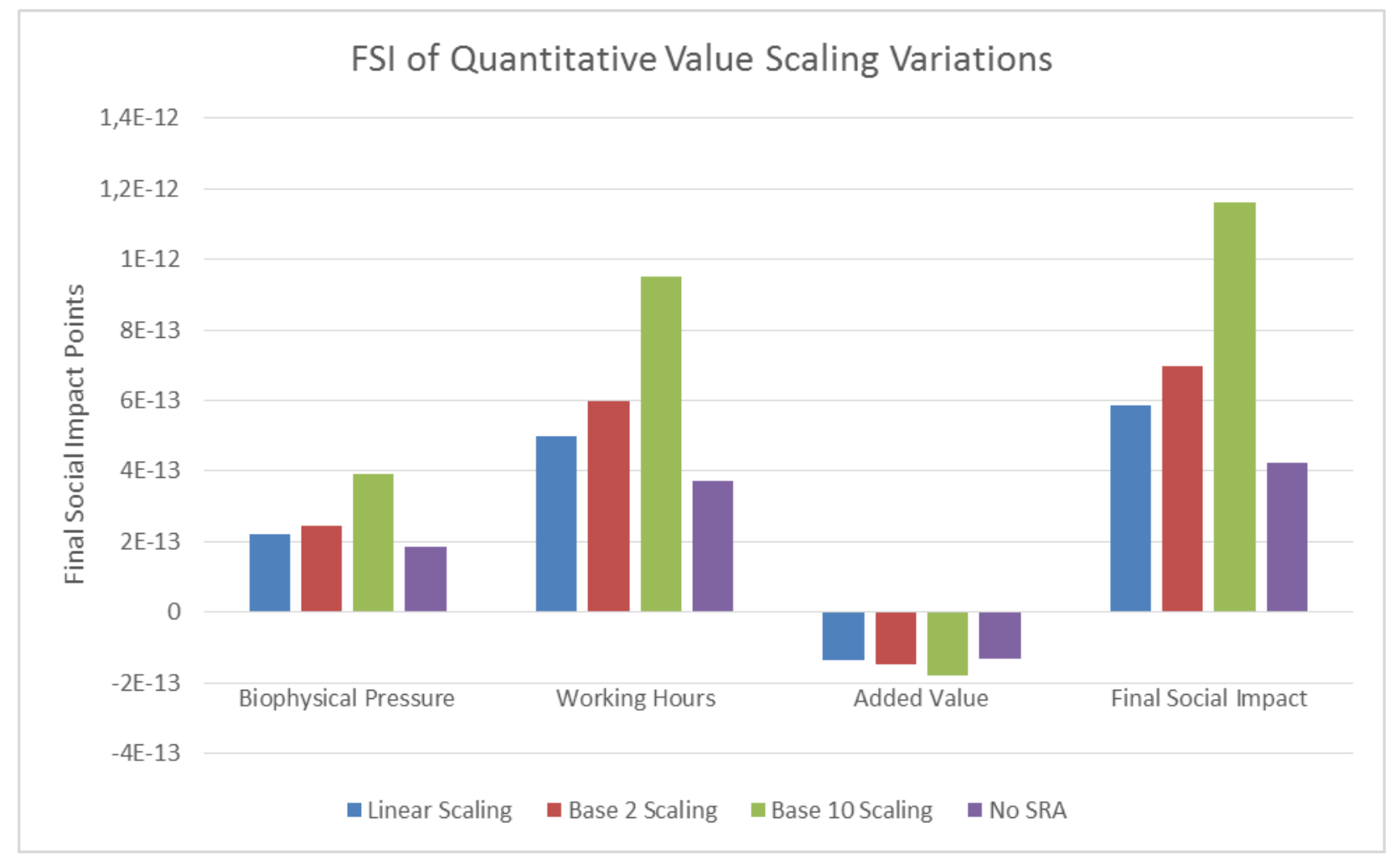

Figure S4: FSI, BP, WH and AV of the quantitative value scaling variations of the default product system. 


\section{S5. Product Systems of the Case Studies}

The following tables show the allocation of the retail price to the different processes in the foreground system. This serves as input to the MRIO based SLCA assessment (background data).

Table S2: H\&M (Cotton) t-shirt foreground processes and corresponding CSS in EXIOBASE and SHDB (according to[2], [3]).

\begin{tabular}{|c|c|c|c|c|c|c|}
\hline \multicolumn{3}{|c|}{$\underline{\text { H\&M T-shirt }}$} & \multicolumn{2}{|r|}{ EXIOBASE } & \multicolumn{2}{|r|}{ SHDB } \\
\hline $\begin{array}{l}\text { Production steps (foreground } \\
\text { processes) }\end{array}$ & Country & $\begin{array}{c}\text { Monetary } \\
\text { Contribution } \\
(€)\end{array}$ & Country & Sector & Country & Sector \\
\hline 1. Cotton (H\&M Case) & USA & 0,4 & US & Cultivation of plant-based fibres & US & Crops nec ${ }^{2}$ \\
\hline \multirow[b]{2}{*}{ 2. Production } & \multirow{2}{*}{ Bangladesh } & 0,475 & WA & a. Manufacture of textiles & $\mathrm{BD}$ & a. Textiles \\
\hline & & 0,475 & WA & $\begin{array}{l}\text { b. Manufacture of wearing apparel; } \\
\text { dressing and dyeing of fur }\end{array}$ & $\mathrm{BD}$ & b. Wearing apparel \\
\hline 3. Transport (shipping) & Malaysia & 0,06 & WA & Sea and coastal water transport & MY & Water transport \\
\hline \multirow[t]{2}{*}{$\begin{array}{l}\text { 4. Wages, Administration, Rent, } \\
\text { Inland Transportation }\end{array}$} & \multirow[t]{2}{*}{ Germany } & 1,8375 & $\mathrm{DE}$ & $\begin{array}{l}\text { a. Retail trade, except of motor vehicles } \\
\text { and motorcycles; repair of personal } \\
\text { and household goods }\end{array}$ & $\mathrm{DE}$ & a. Commerce \\
\hline & & 0,2625 & $\mathrm{DE}$ & b. Other land transport & $\mathrm{DE}$ & b. Transport nec ${ }^{2}$ \\
\hline 5. Value added taxes & Germany & 0,79 & $\mathrm{DE}$ & $\begin{array}{l}\text { Public administration and defence; } \\
\text { compulsory social security }\end{array}$ & $\mathrm{DE}$ & $\begin{array}{l}\text { Public Administration, } \\
\text { Defence, Education, Health }\end{array}$ \\
\hline 6. Profit & Sweden & 0,65 & SE & $\begin{array}{l}\text { Retail trade, except of motor vehicles and } \\
\text { motorcycles; repair of personal and } \\
\text { household goods }\end{array}$ & SE & Commerce \\
\hline \multicolumn{2}{|l|}{ Price in Store } & \multicolumn{5}{|l|}{4,95} \\
\hline
\end{tabular}


Table S3: Polyester (H\&M) t-shirt foreground processes and corresponding CSS in EXIOBASE and SHDB (according to [2]-[4]).

\begin{tabular}{|c|c|c|c|c|c|c|}
\hline \multicolumn{3}{|c|}{ Polyester T-shirt } & \multicolumn{2}{|r|}{ EXIOBASE } & \multicolumn{2}{|r|}{ SHDB } \\
\hline $\begin{array}{c}\text { Production steps (foreground } \\
\text { processes) }\end{array}$ & Country & $\begin{array}{c}\text { Monetary } \\
\text { Contribution } \\
(€)\end{array}$ & Country & Sector & Country & Sector \\
\hline 1. Polyester & Iran & 0,4 & WM & $\begin{array}{l}\text { Extraction of crude petroleum and } \\
\text { services related to crude oil extraction, } \\
\text { excluding surveying }\end{array}$ & IR & Oil \\
\hline 2. Production & China & 0,95 & WA & Manufacture of textiles & $\mathrm{BD}$ & Textiles \\
\hline 3. Transport (shipping) & Malaysia & 0,06 & WA & Sea and coastal water transport & MY & Water transport \\
\hline \multirow[t]{2}{*}{$\begin{array}{l}\text { 4. Wages, Administration, Rent, } \\
\text { Inland Transportation }\end{array}$} & \multirow[t]{2}{*}{ Germany } & 1,8375 & $\mathrm{DE}$ & $\begin{array}{l}\text { c. Retail trade, except of motor vehicles } \\
\text { and motorcycles; repair of personal } \\
\text { and household goods }\end{array}$ & DE & c. Commerce \\
\hline & & 0,2625 & $\mathrm{DE}$ & d. Other land transport & $\mathrm{DE}$ & d. Transport nec ${ }^{2}$ \\
\hline 5. Value added taxes & Germany & 0,79 & DE & $\begin{array}{l}\text { Public administration and defence; } \\
\text { compulsory social security }\end{array}$ & DE & $\begin{array}{l}\text { Public Administration, } \\
\text { Defence, Education, Health }\end{array}$ \\
\hline 6. Profit & Sweden & 0,65 & SE & $\begin{array}{l}\text { Retail trade, except of motor vehicles and } \\
\text { motorcycles; repair of personal and } \\
\text { household goods }\end{array}$ & SE & Commerce \\
\hline \multicolumn{2}{|l|}{ Price in Store } & \multicolumn{5}{|l|}{4,95} \\
\hline
\end{tabular}


Table S4: HessNatur t-shirt foreground processes and corresponding CSS in EXIOBASE and SHDB (according to [5]).

\begin{tabular}{|c|c|c|c|c|c|c|}
\hline \multicolumn{3}{|c|}{$\underline{\text { HessNatur T-shirt }}$} & \multicolumn{2}{|r|}{ EXIOBASE } & \multicolumn{2}{|r|}{ SHDB } \\
\hline $\begin{array}{c}\text { Production steps } \\
\text { (foreground processes) }\end{array}$ & Country & $\begin{array}{c}\text { Monetary } \\
\text { Contribution }(€)\end{array}$ & Country & Sector & Country & Sector \\
\hline 1. Cotton & $\begin{array}{l}\text { Burkina } \\
\text { Faso }\end{array}$ & 3,65 & WF & Cultivation of plant-based fibres & $\mathrm{SN}^{3}$ & Crops nec ${ }^{2}$ \\
\hline 2. Transport (railways) & $\begin{array}{l}\text { Burkina } \\
\text { Faso }\end{array}$ & 0,03 & WF & Transport via railways & $\mathrm{SN}^{3}$ & Transport nec ${ }^{2}$ \\
\hline 3. Transport (shipping) & Ivory Coast & 0,03 & WF & Sea and coastal water transport & $\mathrm{SN}^{3}$ & Water transport \\
\hline 4. Textile production & Greece & 2,095 & GR & Manufacture of textiles & GR & Textiles \\
\hline $\begin{array}{l}\text { 5. Production of } \\
\text { wearing apparel }\end{array}$ & Greece & 0,745 & $\mathrm{GR}$ & $\begin{array}{l}\text { Manufacture of wearing apparel; dressing and } \\
\text { dyeing of fur }\end{array}$ & $\mathrm{GR}$ & Wearing apparel \\
\hline 6. Transport (truck) & Greece & 0,12 & $\mathrm{GR}$ & Other land transport & GR & Transport nec ${ }^{2}$ \\
\hline 7. Retail and Profit & Germany & 3,19 & $\mathrm{DE}$ & $\begin{array}{l}\text { Public administration and defence; compulsory } \\
\text { social security }\end{array}$ & $\mathrm{DE}$ & $\begin{array}{l}\text { Public Administration, } \\
\text { Defence, Education, Health }\end{array}$ \\
\hline 8. Added value taxes & Germany & 10,1 & $\mathrm{DE}$ & $\begin{array}{l}\text { Retail trade, except of motor vehicles and } \\
\text { motorcycles; repair of personal and household } \\
\text { goods }\end{array}$ & $\mathrm{DE}$ & Commerce \\
\hline Price in Store & & 19,95 & & & & \\
\hline
\end{tabular}

${ }^{2}$ nec stands for "not elsewhere classified". ${ }^{3}$ Senegal was taken for Burkina Faso, since their population and HDI is similar. 
Table S5: Heating systems foreground processes and corresponding CSS in EXIOBASE and SHDB (according to [6]-[9] and information in the Electronic Supplementary Material).

\begin{tabular}{|c|c|c|c|c|c|c|}
\hline \multirow{2}{*}{$\begin{array}{l}\text { Heating Systems } \\
\text { Foreground Process }\end{array}$} & \multicolumn{4}{|c|}{ Monetary Value (Euro/kWh) } & \multicolumn{2}{|c|}{ Database Assignments } \\
\hline & $\begin{array}{l}\text { Heat pump (average } \\
\text { electricity mix) }\end{array}$ & $\begin{array}{l}\text { Heat pump (PV } \\
\text { electricity) }\end{array}$ & $\begin{array}{l}\text { Heating unit } \\
\text { (Oil) }\end{array}$ & $\begin{array}{l}\text { Heating unit } \\
\text { (Gas) }\end{array}$ & County (SHDB) & Sector (EXIOBASE) \\
\hline \multirow{2}{*}{ Production of the heating system } & 0,0610 & 0,0610 & & & Switzerland & $\begin{array}{l}\text { Manufacture of electrical machinery and } \\
\text { apparatus nec }{ }^{2}\end{array}$ \\
\hline & 0,0610 & 0,0610 & 0,0849 & 0,0645 & Switzerland & $\begin{array}{l}\text { Manufacture of machinery and equipment } \\
\text { nec }^{2}\end{array}$ \\
\hline \multirow{4}{*}{ Energy Carrier } & & 0,0479 & & & Switzerland & $\begin{array}{l}\text { Production of electricity by solar } \\
\text { photovoltaic }\end{array}$ \\
\hline & 0,0479 & & & & Switzerland & Production of electricity nec ${ }^{2}$ \\
\hline & & & & 0,0901 & Netherlands & $\begin{array}{l}\text { Manufacture of gas; distribution of } \\
\text { gaseous fuels through mains }\end{array}$ \\
\hline & & & 0,0918 & & Germany & Petroleum Refinery \\
\hline
\end{tabular}




\begin{tabular}{|c|c|c|c|c|c|c|c|c|c|c|c|c|}
\hline \multicolumn{13}{|c|}{ Biophysical Pressure Impact of T-shirts } \\
\hline \multirow{10}{*}{ 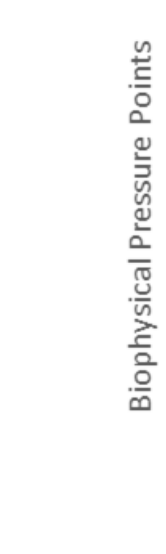 } & \multicolumn{12}{|l|}{$\begin{array}{l}2,00 \mathrm{E}-12 \\
1,80 \mathrm{E}-12\end{array}$} \\
\hline & \multicolumn{12}{|l|}{$\begin{array}{l}1,80 \mathrm{E}-12 \\
1,60 \mathrm{E}-12\end{array}$} \\
\hline & \multicolumn{12}{|l|}{$1,40 \mathrm{E}-12$} \\
\hline & \multicolumn{12}{|l|}{$1,20 \mathrm{E}-12$} \\
\hline & \multicolumn{12}{|l|}{$1,00 \mathrm{E}-12$} \\
\hline & \multicolumn{12}{|l|}{$8,00 \mathrm{E}-13$} \\
\hline & \multicolumn{11}{|l|}{$6,00 \mathrm{E}-13$} & \\
\hline & \multicolumn{11}{|l|}{$\begin{array}{l}4,00 \mathrm{E}-13 \\
2,00 \mathrm{E}-13\end{array}$} & \\
\hline & \multirow[t]{2}{*}{$0,00 E+00$} & & & & & & & & & & & \\
\hline & & $\begin{array}{l}\text { Freshwater } \\
\text { ecotoxicity }\end{array}$ & $\begin{array}{c}\text { Freshwater } \\
\text { eutrophicati } \\
\text { on }\end{array}$ & $\begin{array}{l}\text { Heat } \\
\text { rejected to } \\
\text { freshwater }\end{array}$ & $\begin{array}{l}\text { Human } \\
\text { toxicity }\end{array}$ & Land use & $\begin{array}{l}\text { Particulate } \\
\text { matter } \\
\text { formation }\end{array}$ & $\begin{array}{l}\text { Photochemi } \\
\text { cal oxidant } \\
\text { formation }\end{array}$ & $\begin{array}{l}\text { Terrestrial } \\
\text { acidification }\end{array}$ & $\begin{array}{l}\text { Terrestrial } \\
\text { ecotoxicity }\end{array}$ & Water use & Total BP \\
\hline \multicolumn{2}{|l|}{ 口 H\&M } & 9,51E-19 & $6,08 \mathrm{E}-18$ & $2,90 \mathrm{E}-20$ & $9,06 \mathrm{E}-14$ & $5,54 \mathrm{E}-14$ & $7,01 \mathrm{E}-14$ & $2,86 \mathrm{E}-15$ & $8,54 \mathrm{E}-18$ & $1,86 \mathrm{E}-19$ & $2,80 \mathrm{E}-15$ & $2,22 \mathrm{E}-13$ \\
\hline \multicolumn{2}{|l|}{ - HessNatur } & $7,03 E-19$ & $5,69 \mathrm{E}-17$ & $6,16 \mathrm{E}-20$ & $5,83 \mathrm{E}-14$ & $1,52 \mathrm{E}-12$ & $1,50 \mathrm{E}-13$ & $9,53 \mathrm{E}-15$ & $2,05 \mathrm{E}-17$ & $1,24 \mathrm{E}-19$ & $2,74 \mathrm{E}-14$ & $1,77 \mathrm{E}-12$ \\
\hline \multicolumn{2}{|c|}{ Polyester } & $9,46 \mathrm{E}-19$ & $1,35 \mathrm{E}-17$ & $2,86 \mathrm{E}-20$ & $8,85 \mathrm{E}-14$ & $4,51 \mathrm{E}-14$ & $1,04 \mathrm{E}-13$ & $4,96 \mathrm{E}-15$ & $1,62 \mathrm{E}-17$ & $1,82 \mathrm{E}-19$ & $2,16 \mathrm{E}-15$ & $2,45 \mathrm{E}-13$ \\
\hline \multicolumn{2}{|c|}{ - HessNatur (No Cotton) } & $3,60 \mathrm{E}-21$ & $4,20 \mathrm{E}-20$ & $8,38 \mathrm{E}-22$ & $3,12 \mathrm{E}-16$ & $5,20 \mathrm{E}-16$ & $7,83 \mathrm{E}-16$ & $3,39 \mathrm{E}-17$ & $1,06 \mathrm{E}-19$ & $6,29 \mathrm{E}-22$ & $2,12 \mathrm{E}-17$ & $1,67 \mathrm{E}-15$ \\
\hline
\end{tabular}

Figure S5: BP of the three t-shirt alternatives divided into the midpoint shares. 


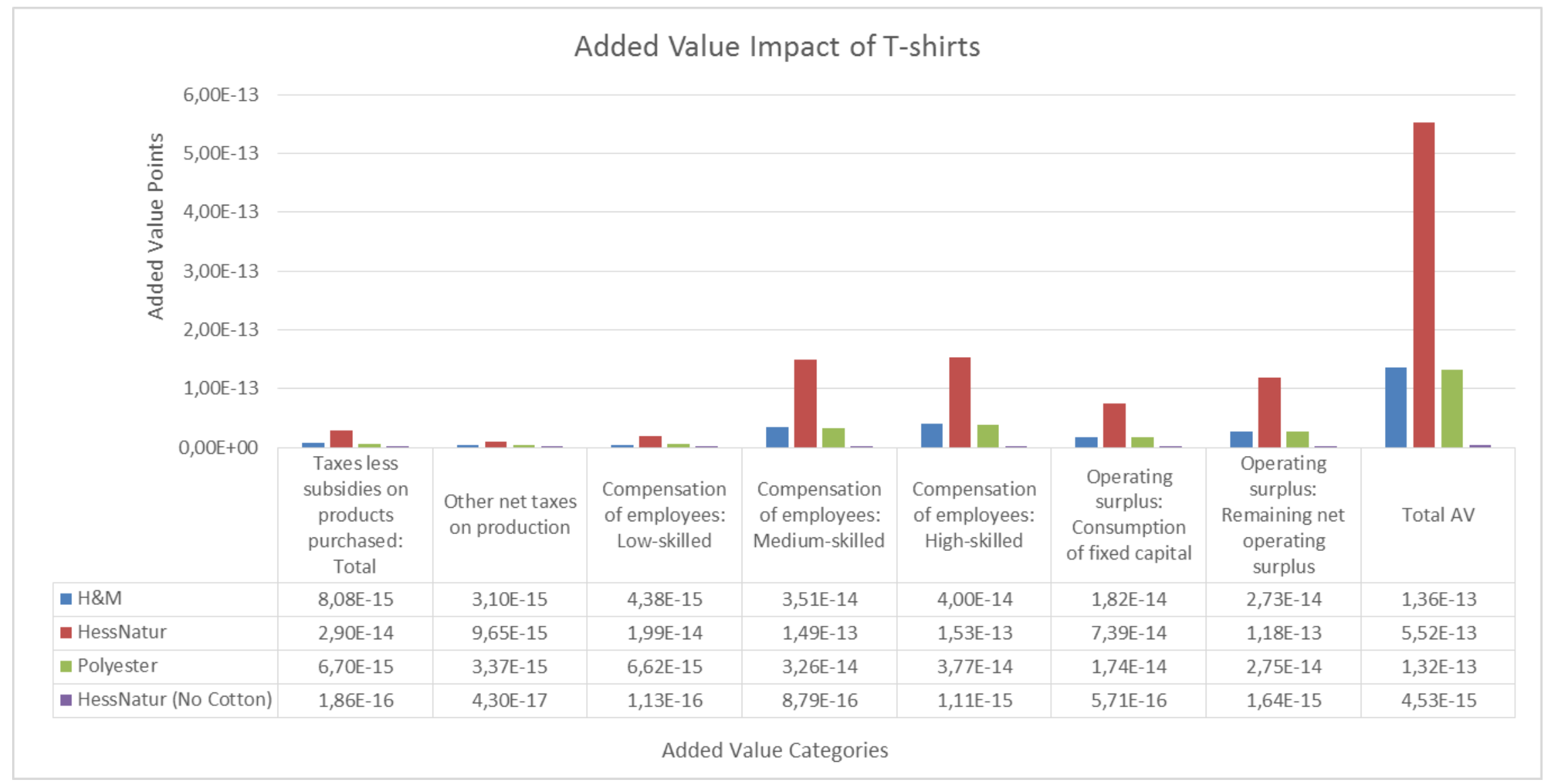

Figure S6: AV of the three t-shirt alternatives divided into the Added Value category shares. 


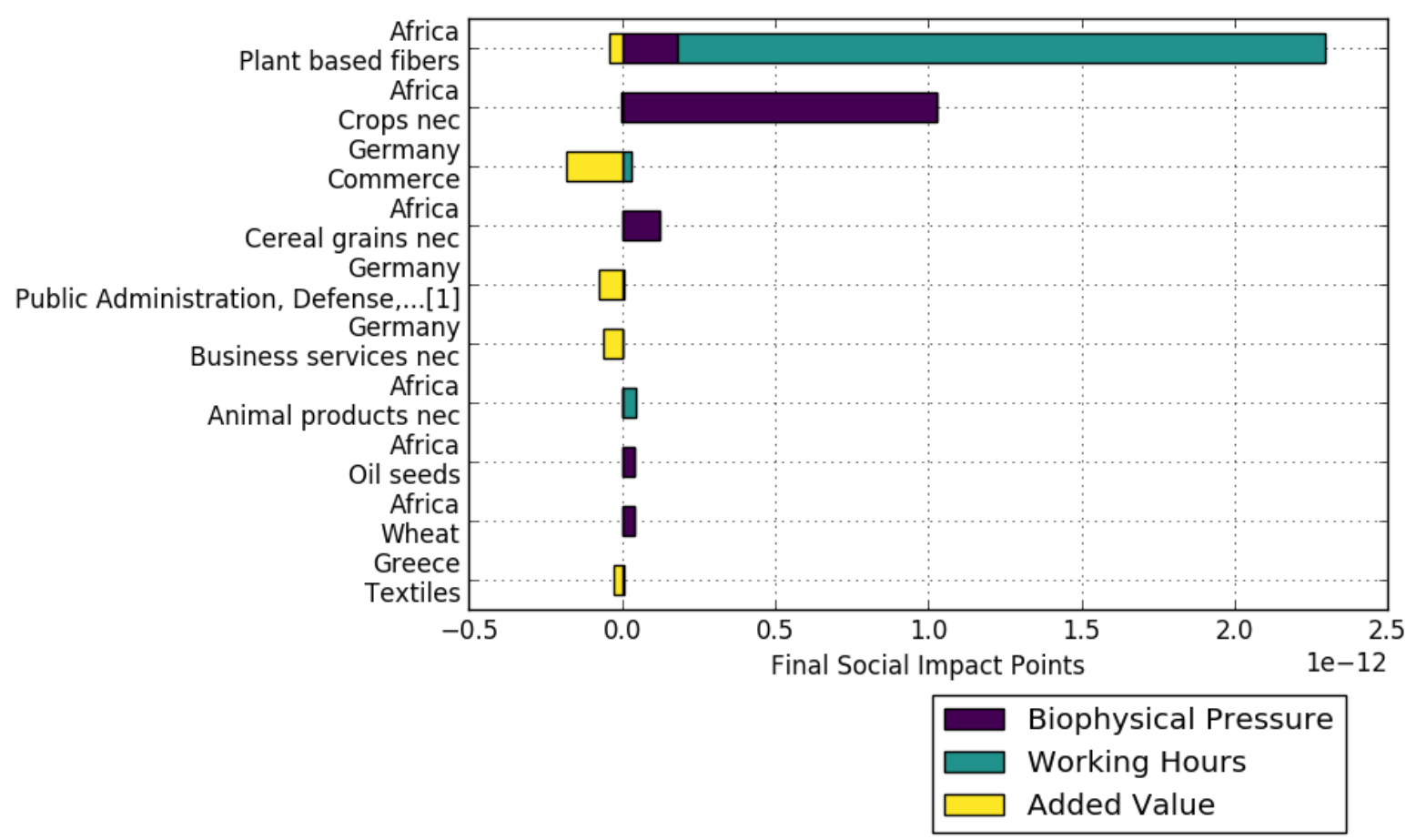

Figure S7: Ten most contributing CSS of the HessNatur t-shirt (20€) FSI divided into the activity variable shares. 


\section{S7. Additional Results of Heating System Case Study}

The full results of the product systems are provided in the electronic supporting information as XLS tables).

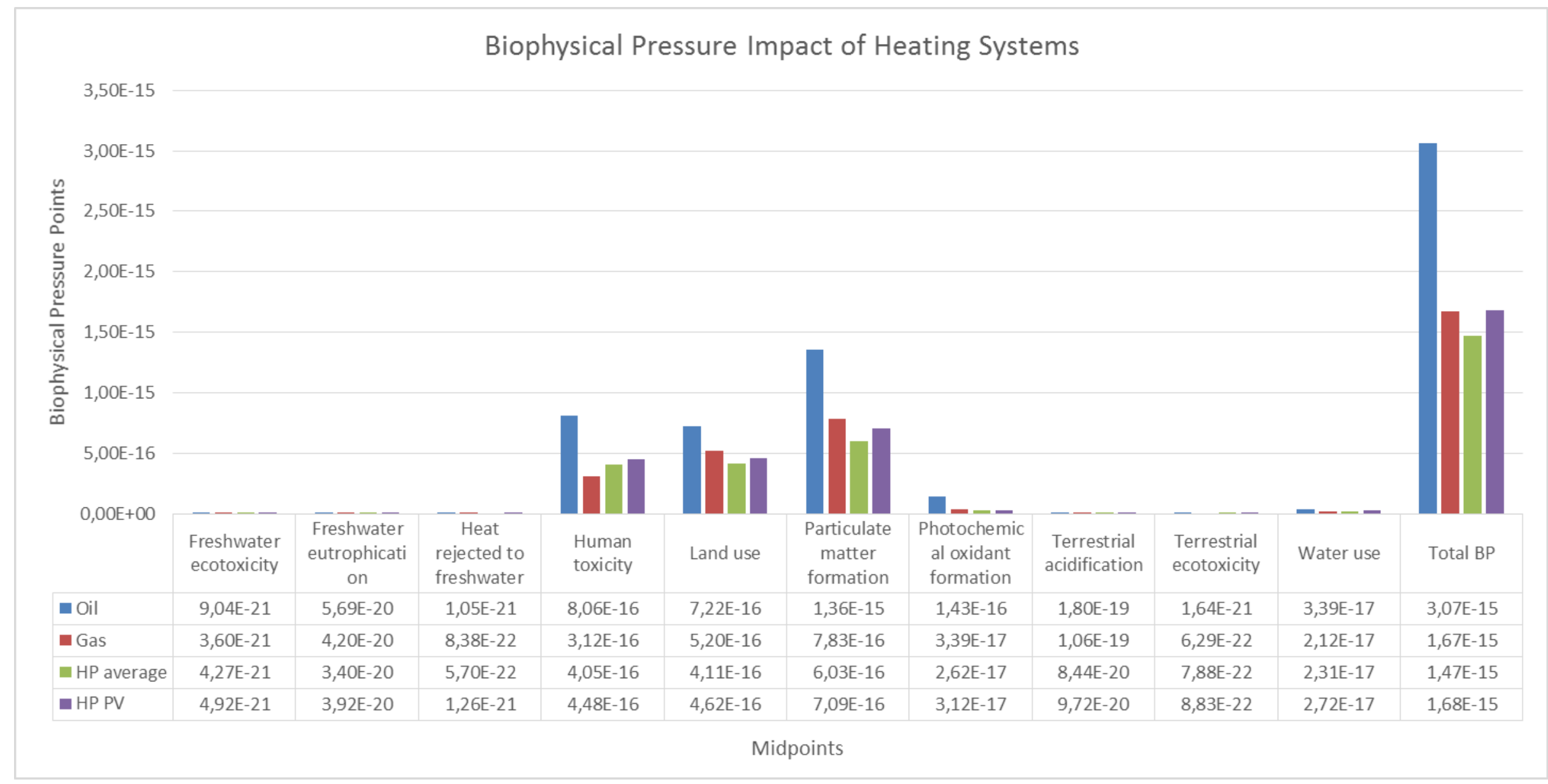

Figure S8: BP of the four heating system alternatives divided into the midpoint shares. 


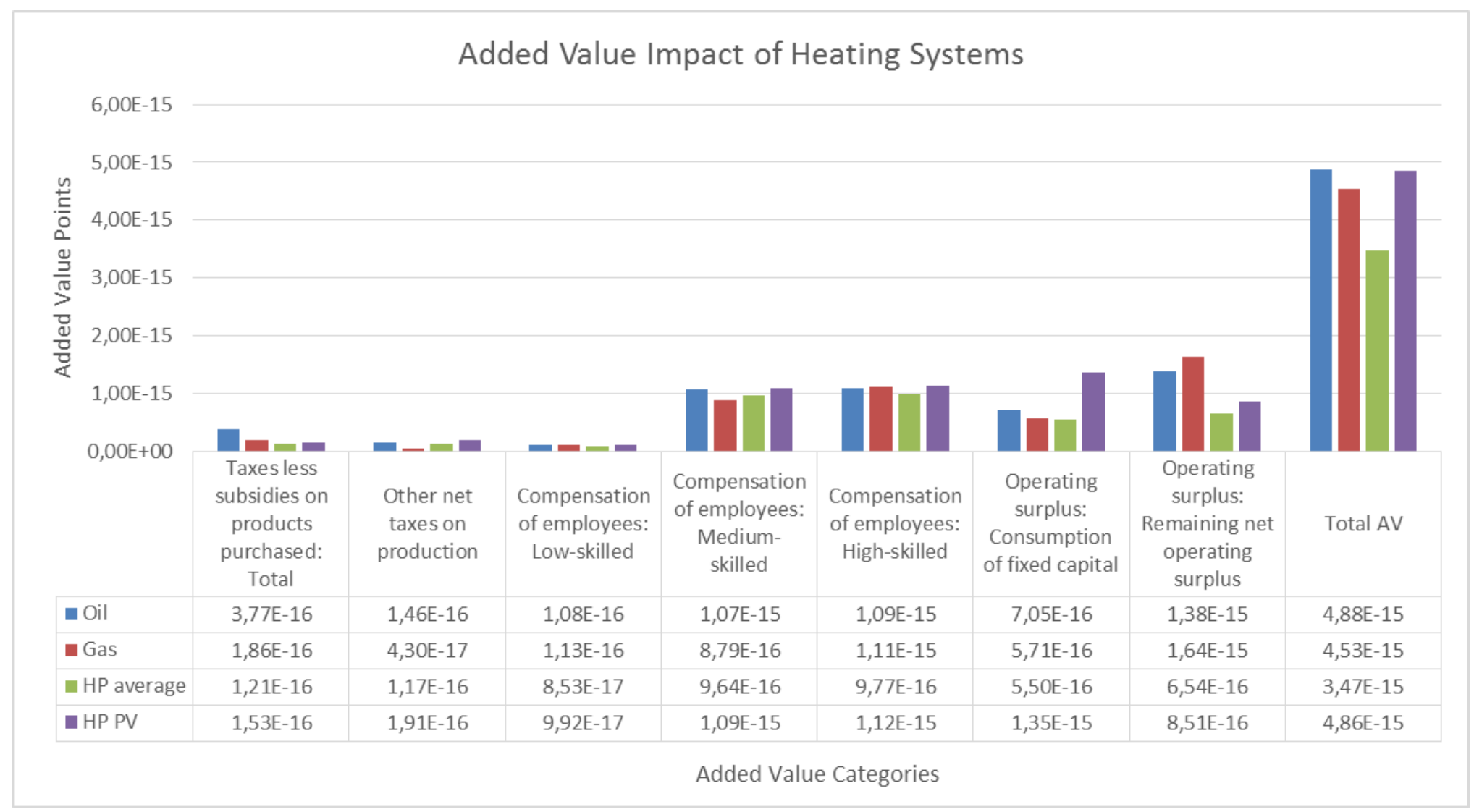

Figure S9: AV of the four heating system alternatives divided into the Added Value category shares. 


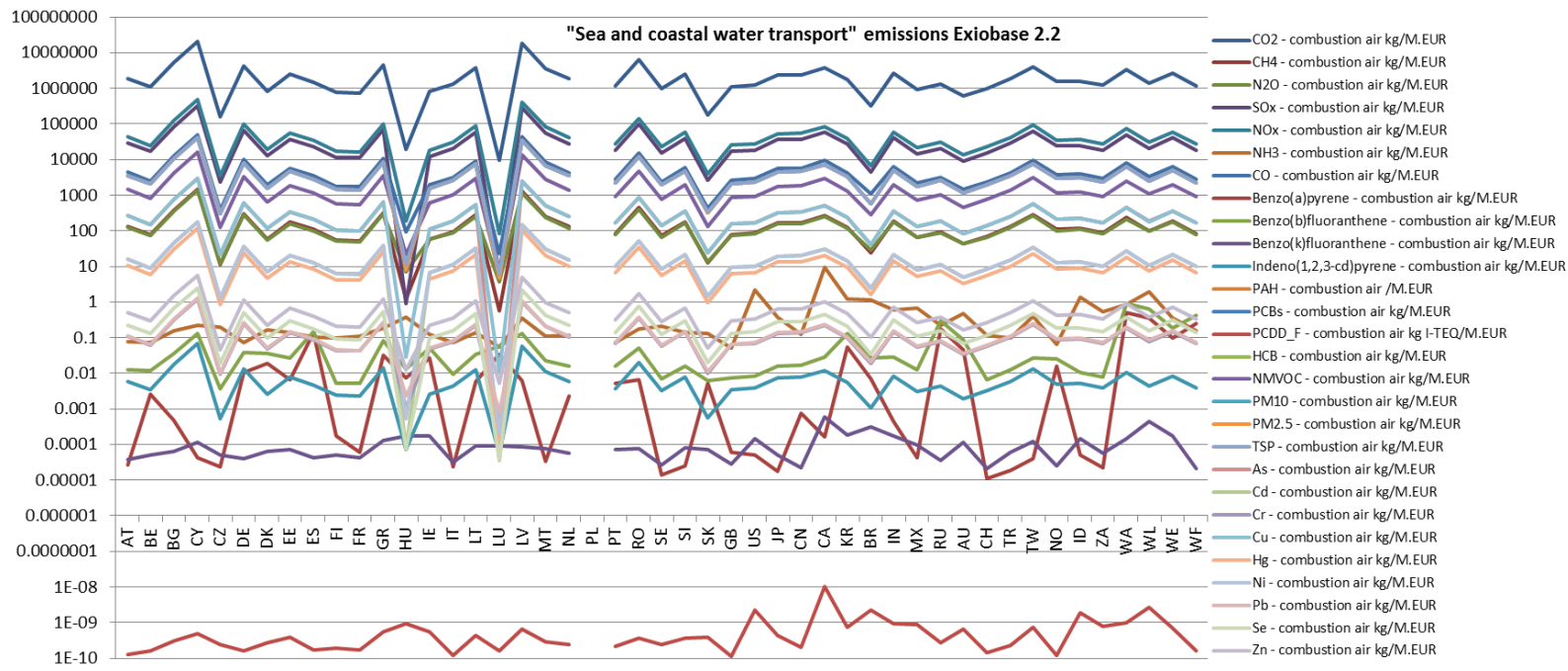

Figure S10: Emissions of most polluting substances in the sector "sea and coastal water transport" for all the regions in Exiobase v 2.2 [10]. 


\section{References}

[1] OANDA Corporation, "Average exchange rates," 2015. [Online]. Available: http://www.oanda.com/currency/.

[2] H\&M, “H\&M Annual Report 2013," 2013. [Online]. Available: http://about.hm.com/content/dam/hm/about/documents/en/Annual Report/Annual-Report2013_en.pdf (Accessed 06.04.2015).

[3] W. Uchatius, "Das Welthemd. Der Modekonzern H\&M tritt gegen Ausbeutung ein. Und doch verkauft er Kleider für ein paar Euro. Wie kann das sein?," Die Zeit Online, 2010. [Online]. Available: http://www.zeit.de/2010/51 /Billige-T-Shirts (Accessed 06.04.2015).

[4] J. McDonald, "China importiert jetzt mehr Öl als die USA," Tagesanzeiger, 2013.

[5] HessNatur, "Hessnatur Bericht zur Nachhaltigkeit," 2013.

[6] FWS (Fachverein Wärmepumpen Schweiz), "Heizkostenvergleich Einfamilienhaus," 2009. [Online]. Available: www.fws.ch/tl_files/download_d/Downloads/kopie_von_heizkostenvergleich_efh_april2009_d_2_.xls? phpMyAdmin=6b841e574b7e027ebeb2ac08849f32af.

[7] FWS (Fachverein Wärmepumpen Schweiz), "Heizkostenvergleich Mehrfamilienhaus," 2009. [Online]. Available: www.fws.ch/tl_files/download_d/Downloads/heizkostenvergleich_mfh_april2009_d.xls?phpMyAdmin=6 b841e574b7e027ebeb2ac08849f32af.

[8] BFS (Bundesamt für Statistik Schweiz), "Gebäude nach Gebäudekategorie und Geschosszahl," 2016. [Online]. Available: http://www.bfs.admin.ch/bfs/portal/de/index/themen/09/02/blank/key/gebaeude/art_und_groesse.ht $\mathrm{ml}$.

[9] Erdgas Schweiz, "Kostenvergleich verschiedener Heizsysteme," 2015. [Online]. Available: https://www.erdgas.ch/fileadmin/customer/erdgasch/Data/Erdgas/Preise/kostenvergleich_d.pdf.

[10] Wood R, Stadler K, Bulavskaya T, et al (2015) Global sustainability accounting-developing EXIOBASE for multi-regional footprint analysis. Sustain 7:138-163. doi: 10.3390/su7010138 
Figure 1: Structure of developed S-LCA method embedded in the LCA frame. Blue boxes are novel contributions by this work, orange boxes represent input from the SHDB (Benoit-Norris 2012) and the green box represents input from Exiobase v2.2.2 (Wood et al. 2015).

Figure 2: Scheme of the calculation steps for the three activity variables (A) Working Hours, (B) Biophysical Pressure and (C) Added Value. Orange boxes represent input from the SHDB (Benoit-Norris 2012) and the green box represents input from Exiobase v2.2.2 (Wood et al. 2015). The outputs contain ratios of product/service impacts compared to activity resulting from annual consumption (normalized results) to make it comparable. Abbreviations: L-Inverse: Leontief Inverse Matrix Calculation; Norm factor: Normalisation factor; Endp. Weigt: Endpoint Weighting; RoW: Rest of World; AV categories: Added Value categories.

Figure 3: Adaptions of ReCiPe method for activity variable Biophysical Pressure (including additional impacts on water and land providing results in ReCiPe units).

Figure 4: Scheme of calculation steps for the SRA. Orange boxes represent input from the SHDB (Benoit-Norris 2012) and the green box respresents input from Exiobase v2.2.2 (Wood et al. 2015). The input risks (cf. Table 2) are transformed to quantitative values (cf. Table 3 ) in Step 1. In the second step the risks per CSS form the SHDB are matched with the CSS in Exiobase for assessing the economic and environmental activity variables to obtain SRF per CSS. In the $3^{\text {rd }}$ step, the SRF are multiplied with the activity variables (step 3 in Figure 2) and normalized by the social impacts of annual consumption, which results in Social Impact Points.

Figure 5: Final Social Impact, Biophysical Pressure, Working Hours and Added Value of the polyester and cotton t-shirt alternatives. HessNatur ( $5 €$ ) and HessNatur (No Cotton) represent hypothetical cases to better understand the systems.

Figure 6: Final Social Impact, Biophysical Pressure, Working Hours and Added Value of the four heating system alternatives.

Figure 7: Final social impact scores for the oil boiler and PV heat pump systems differentiated by the three activity variables: Ten most important CSS for (A) oil and (B) PV, aggregated sectors (SHDB and EXIOBASE) for (C) oil and (D) PV, and countries affected for (E) oil and (F) PV

Figure 8: Social impacts for the three activity variables of the oil heating system: Working Hours per (A) CSS and (B) country, Biophysical Pressure per (C) CSS and (D) country, and Added Value per (E) CSS and (F) country. Subcategories are shown for C-F. 


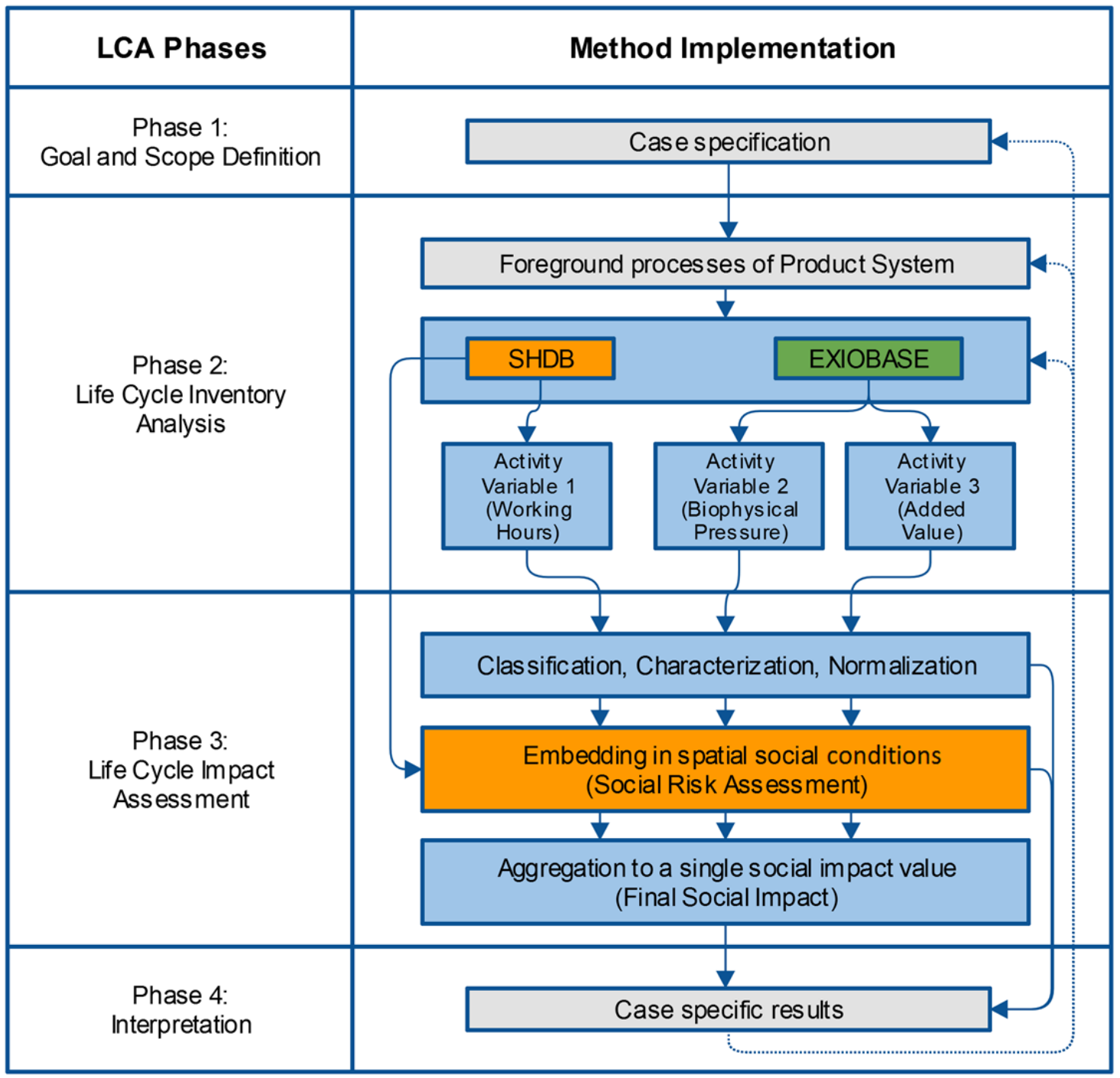

Figure 1: Structure of developed S-LCA method embedded in the LCA frame. Blue boxes are novel contributions by this work, orange boxes represent input from the SHDB (Benoît-Norris 2012) and the green box represents input from Exiobase v2.2.2 (Wood et al. 2015). 

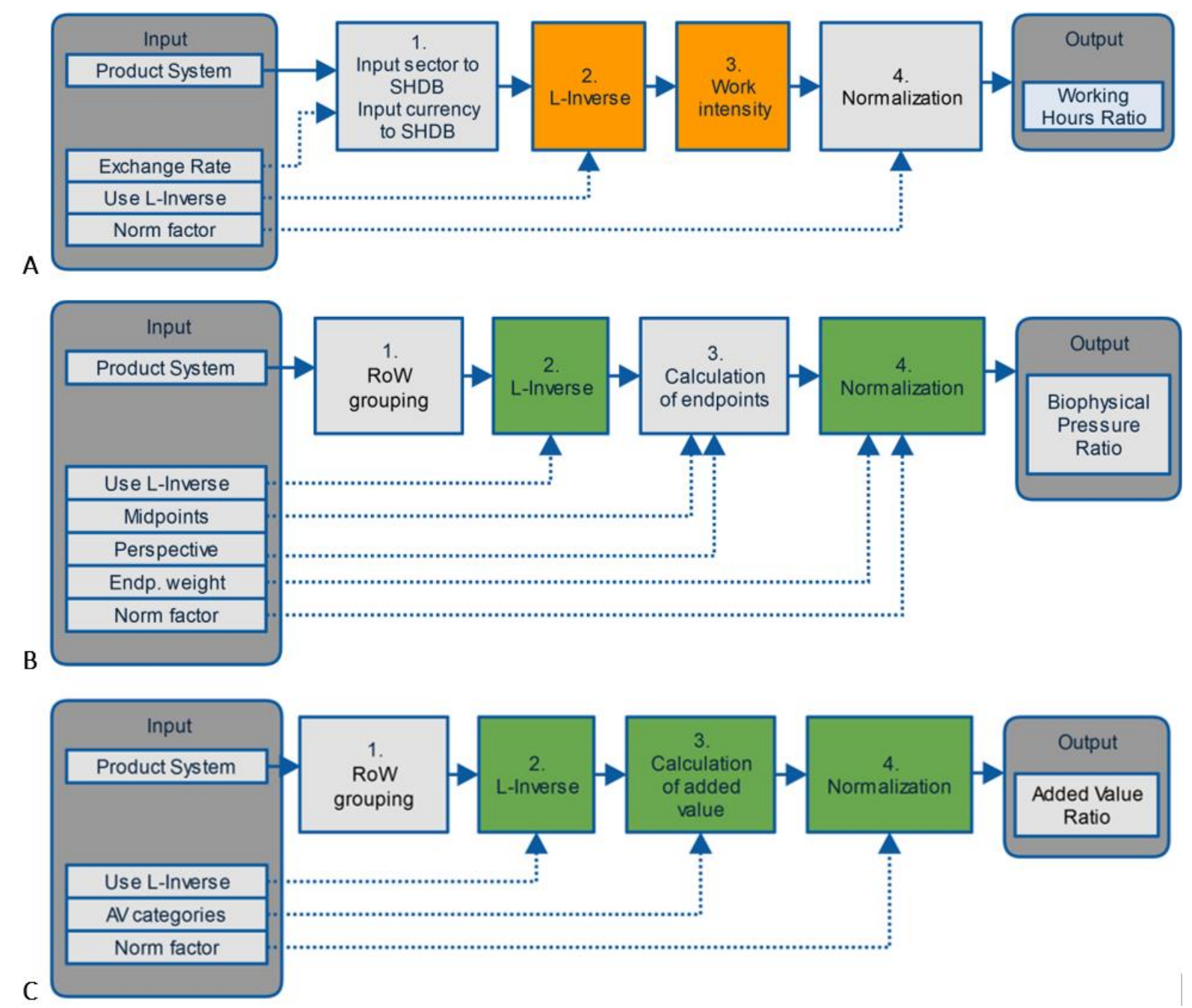

Figure 2: Scheme of the calculation steps for the three activity variables (A) Working Hours, (B) Biophysical Pressure and (C) Added Value. Orange boxes represent input from the SHDB (Benoit-Norris 2012) and the green box represents input from Exiobase v2.2.2 (Wood et al. 2015). The outputs contain ratios of product/service impacts compared to activity resulting from annual consumption (normalized results) to make it comparable. Abbreviations: L-Inverse: Leontief Inverse Matrix Calculation; Norm factor: Normalisation factor; Endp. Weigt: Endpoint Weighting; RoW: Rest of World; AV categories: Added Value categories. 


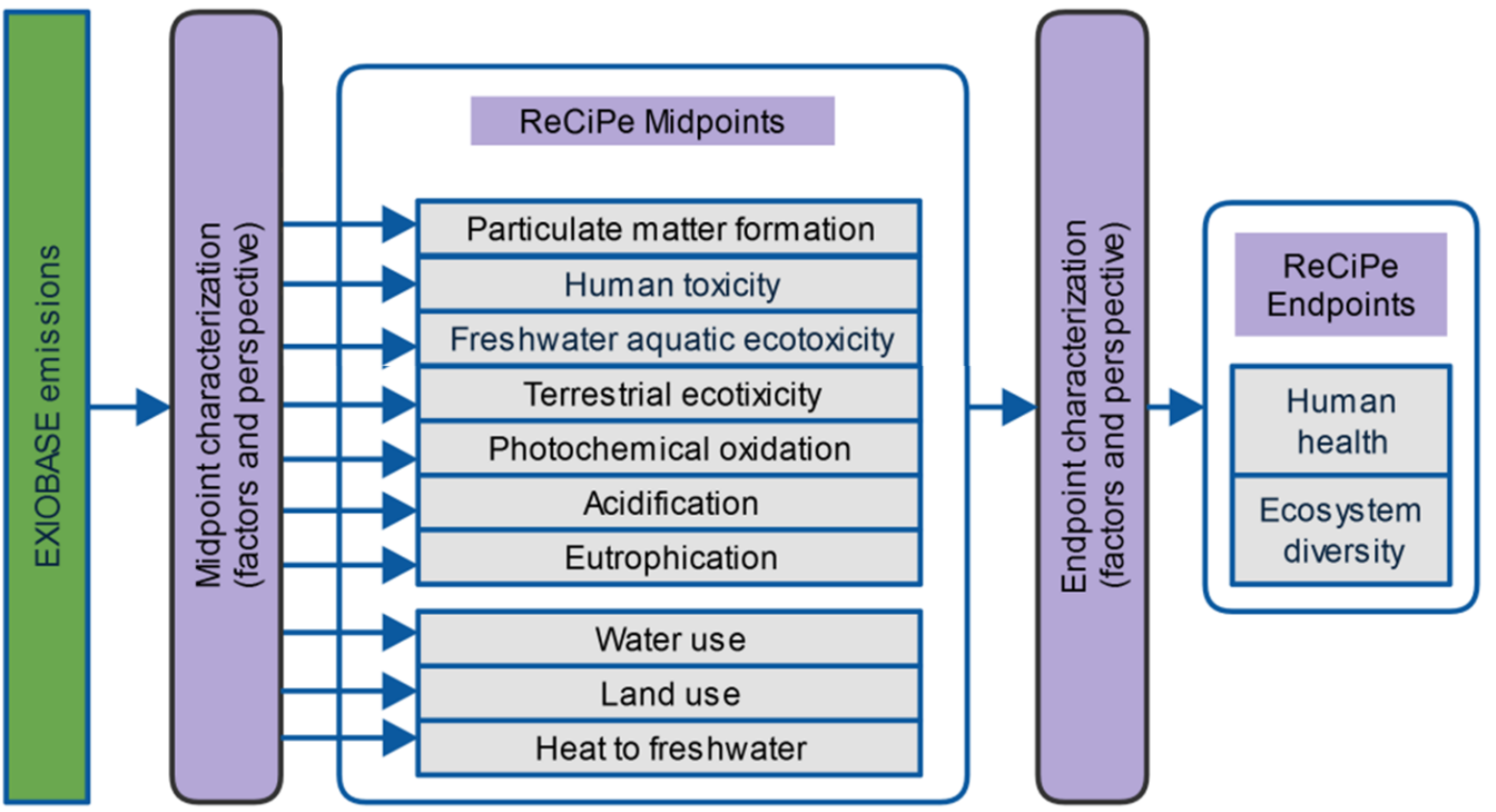

87 Figure 3: Adaptions of ReCiPe method for activity variable Biophysical Pressure (including additional impacts on water and land providing results in ReCiPe units). 


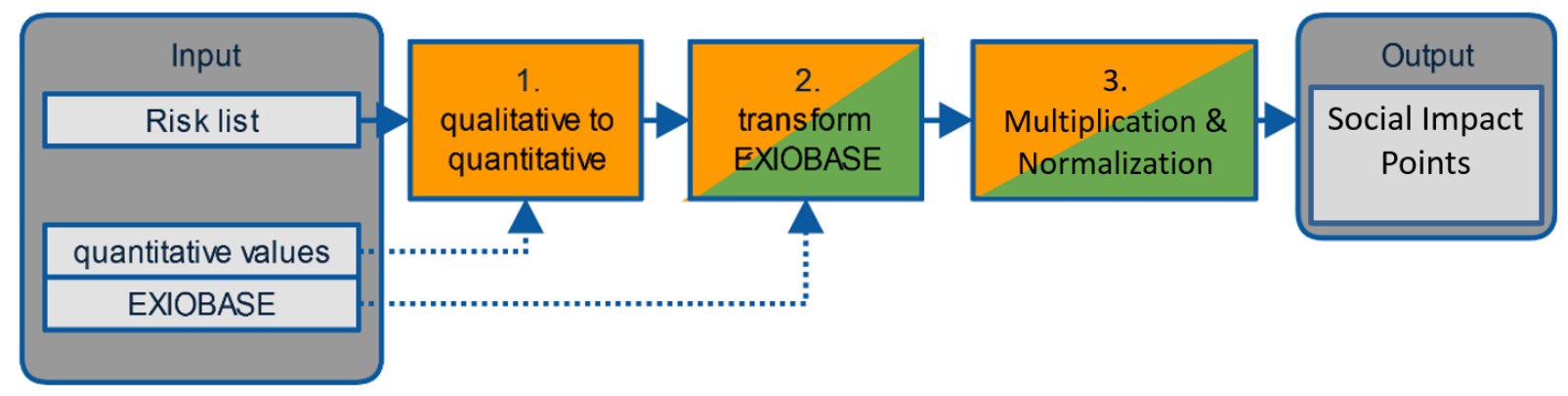

Figure 4: Scheme of calculation steps for the SRA. Orange boxes represent input from the SHDB (Benoit-Norris 2012) and the green box respresents input from Exiobase v2.2.2 (Wood et al. 2015). The input risks (cf. Table 2) are transformed to quantitative values (cf. Table 3) in Step 1. In the second step the risks per CSS form the SHDB are matched with the CSS in Exiobase for assessing the economic and environmental activity variables to obtain SRF per CSS. In the $3^{\text {rd }}$ step, the SRF are multiplied with the activity variables (step 3 in Figure 2) and normalized by the social impacts of annual consumption, which results in Social Impact Points. 
Final Social Impact of T-shirt Alternatives

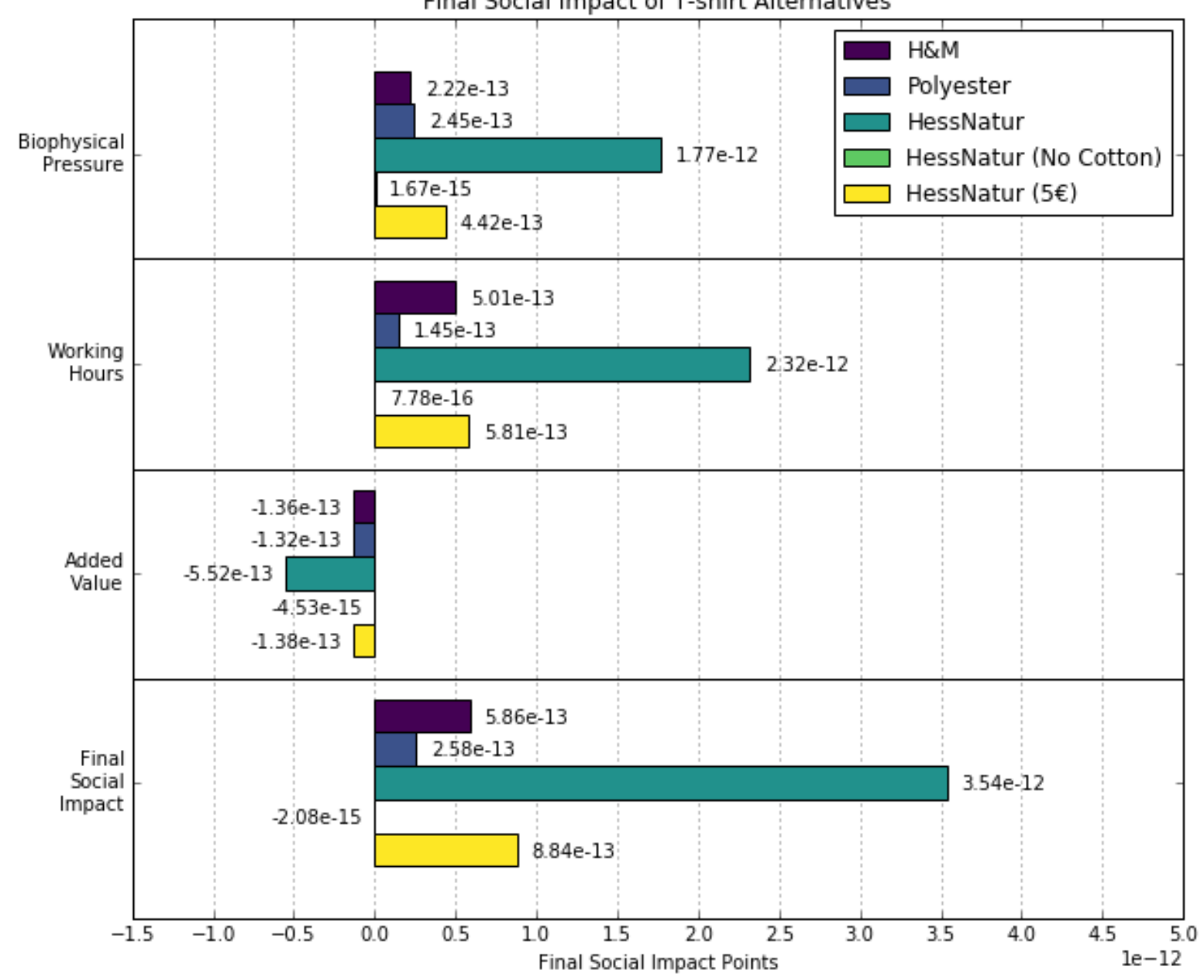

Figure 5: Final Social Impact, Biophysical Pressure, Working Hours and Added Value of the polyester and cotton t-shirt alternatives. HessNatur ( $5 €$ ) and HessNatur (No Cotton) represent hypothetical cases to better understand the systems. 
Final Social Impact of Heating Systems Alternatives

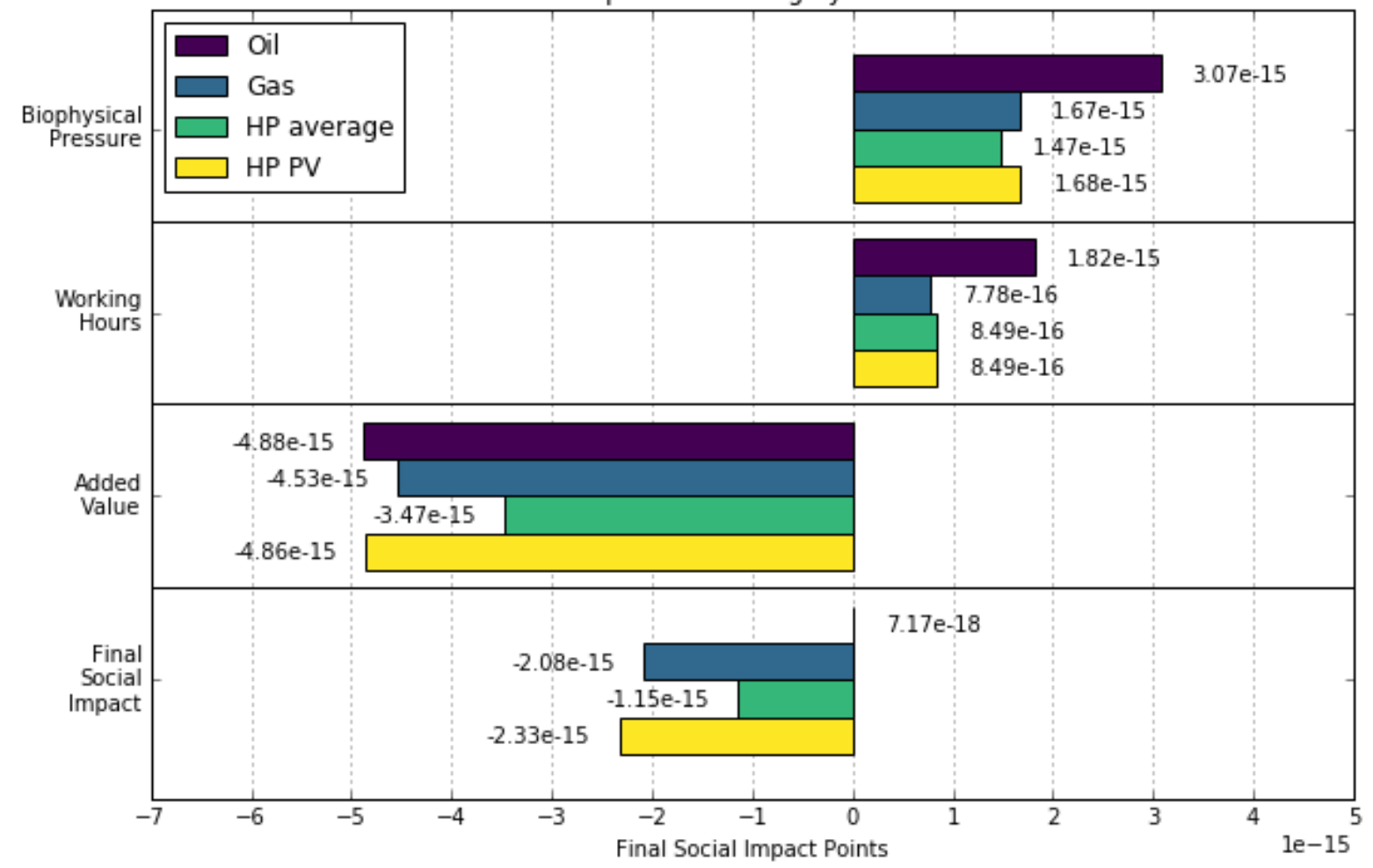

Figure 6: Final Social Impact, Biophysical Pressure, Working Hours and Added Value of the four heating system alternatives. 

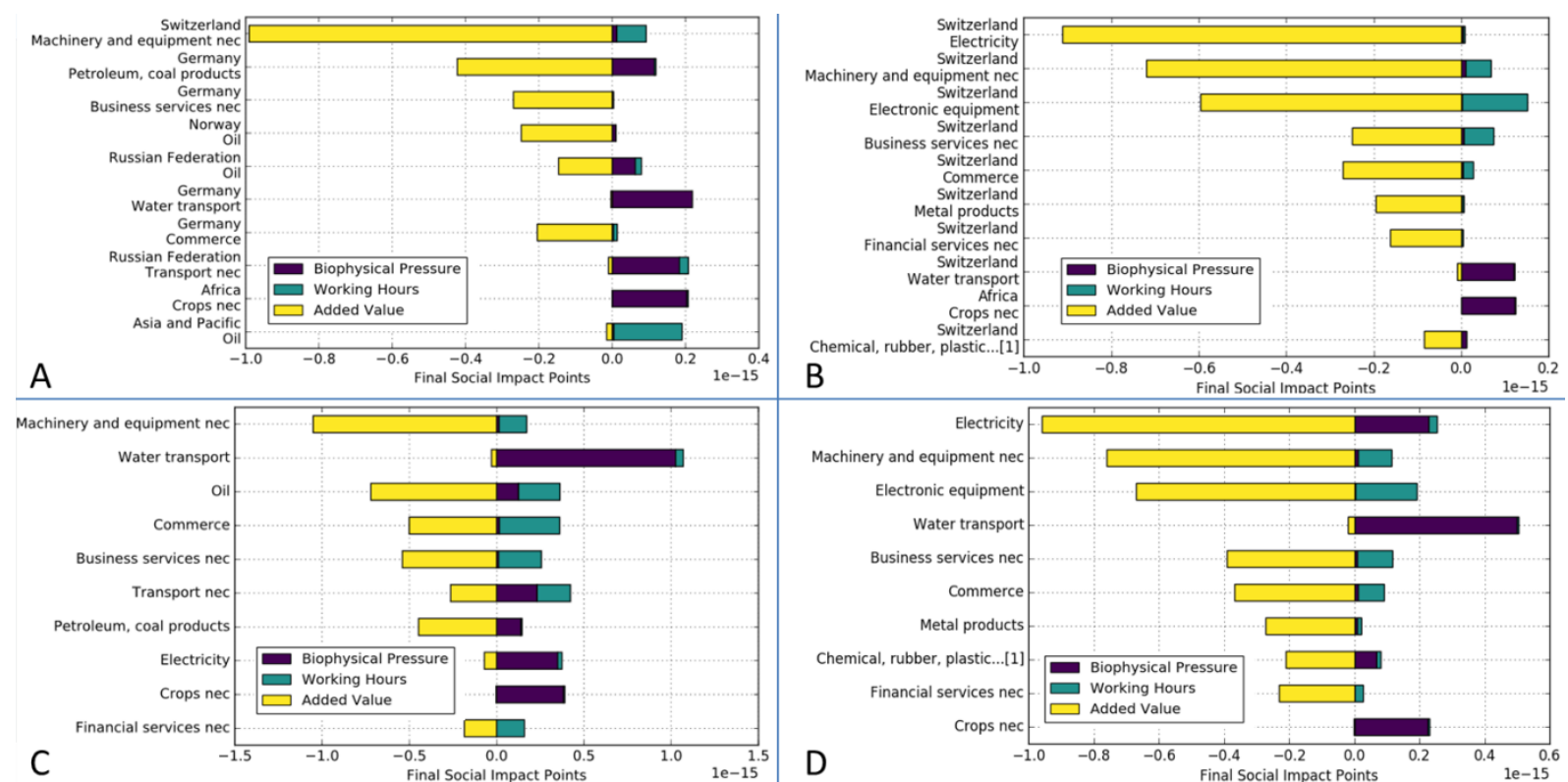

$$
\text { B }
$$
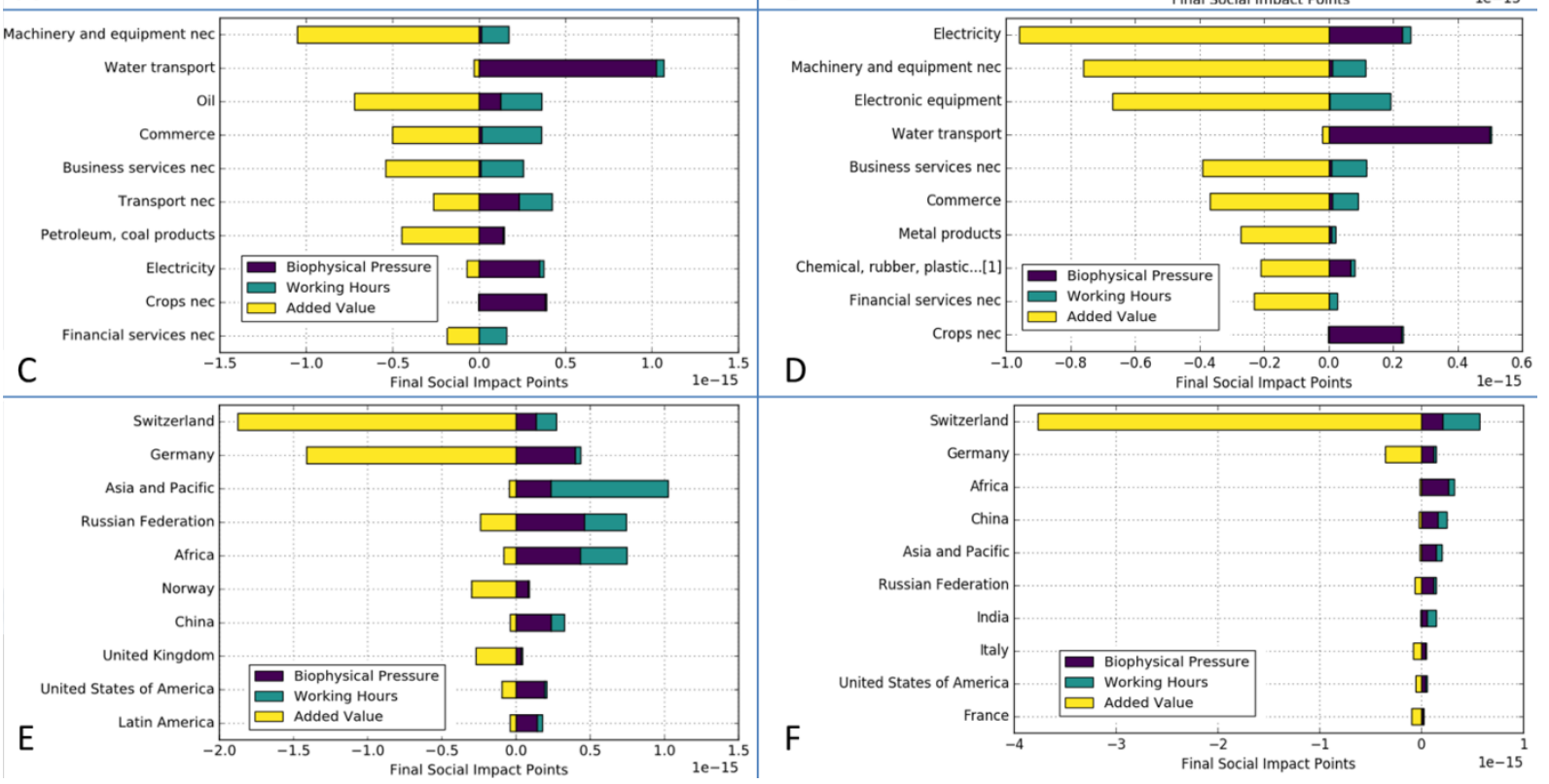

Figure 7: Final social impact scores for the oil boiler and PV heat pump systems differentiated by the three activity variables: Ten most important CSS for (A) oil and (B) PV, aggregated sectors (SHDB and EXIOBASE) for (C) oil and (D) PV, and countries affected for (E) oil and (F) PV 

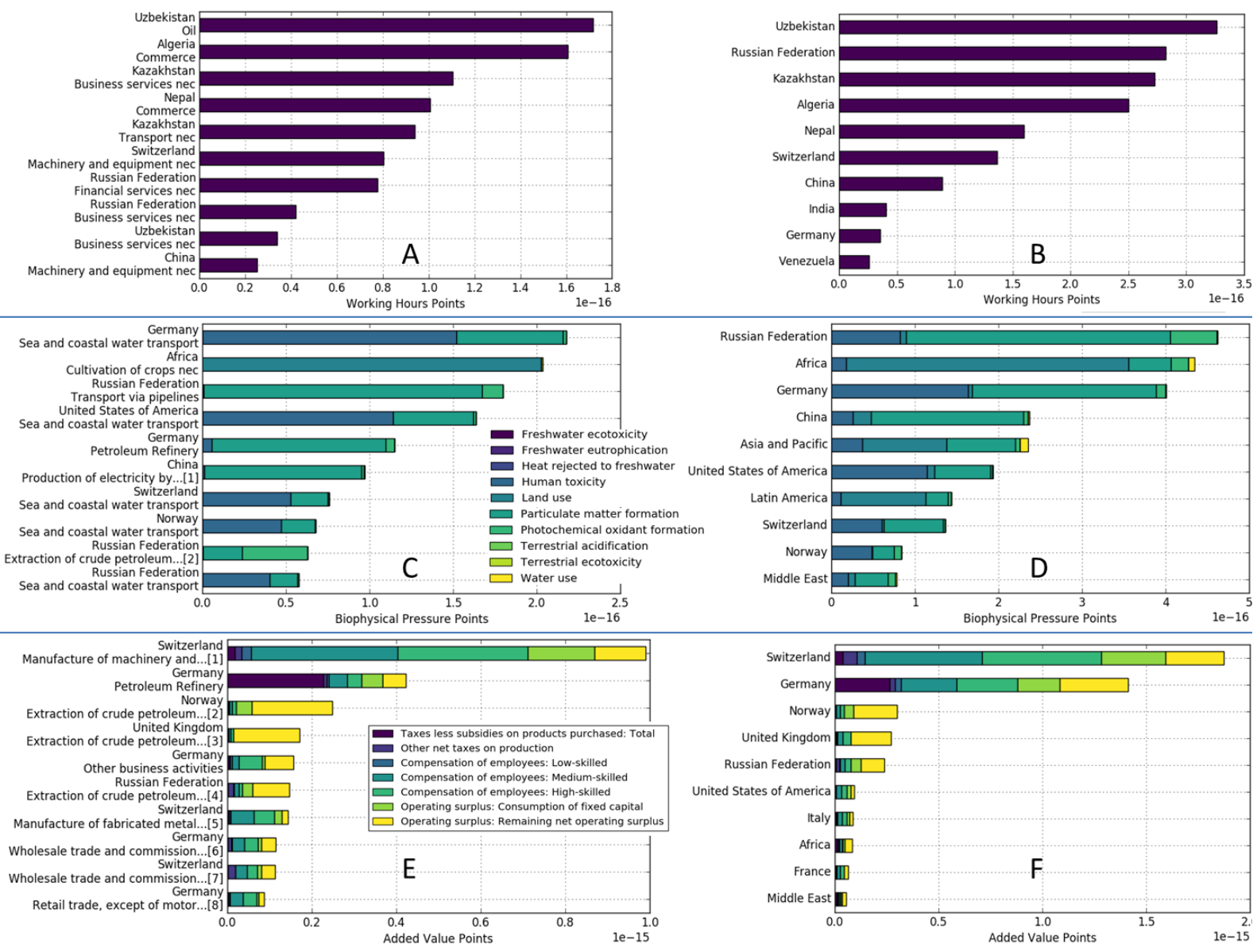

Figure 8: Social impacts for the three activity variables of the oil heating system: Working Hours per (A) CSS and (B) country, Biophysical Pressure per (C) CSS and (D) country, and Added Value per (E) CSS and (F) country. Subcategories are shown for C-F. 